\title{
Sorption of Se species on mineral surfaces, part I : Batch sorption and multi-site modelling
}

\section{$\mathrm{Li}$, Xiaodong}

2018-08

Li , X, Puhakka , E , Ikonen , J , Söderlund, M , Lindberg , A , Holgersson , S , Martin , A \& Siitari-Kauppi , M 2018 , ' Sorption of Se species on mineral surfaces, part I : Batch sorption and multi-site modelling ' , Applied Geochemistry , vol. 95 , pp. 147-157 . https://doi.org/10.1016/j.apgeochem.2018.

http://hdl.handle.net/10138/316255

https://doi.org/10.1016/j.apgeochem.2018.05.024

cc_by_nc

acceptedVersion

Downloaded from Helda, University of Helsinki institutional repository.

This is an electronic reprint of the original article.

This reprint may differ from the original in pagination and typographic detail.

Please cite the original version. 


\section{Sorption of Se species on mineral surfaces, Part I: Batch sorption and multi-site modelling}

Xiaodong Li ${ }^{\mathrm{I}}$, Eini Puhakka ${ }^{\mathrm{I}}$, Jussi Ikonen ${ }^{\mathrm{I}}$, Mervi Söderlund ${ }^{\mathrm{I}}$, Antero Lindberg ${ }^{\mathrm{II}}$, Stellan Holgersson ${ }^{\mathrm{III}}$, Andrew Martin ${ }^{\mathrm{IV}}$, Marja Siitari-Kauppi ${ }^{\mathrm{I}}$

IDepartment of Chemistry, University of Helsinki, P.O. Box 55, FI-00014 University of Helsinki, Finland ${ }^{\mathrm{II} G e o l o g i c a l ~ S u r v e y ~ o f ~ F i n l a n d, ~ B e t o n i m i e h e n k u j a ~ 4, ~ F I-02151 ~ E s p o o, ~ F i n l a n d ~}$

IIIDepartment of Chemical and Biological Engineering, Nuclear Chemistry, Chalmers University of Technology, Kemivägen 4, SE-41296 Göteborg, Sweden

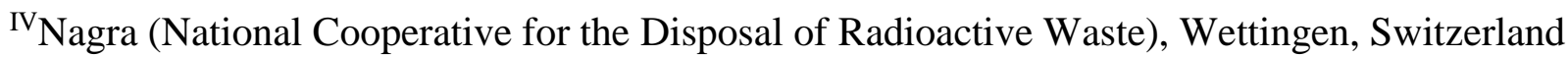

Abstract: The sorption behavior of Se(IV) on Grimsel granodiorite and its main minerals, plagioclase, K-feldspar, quartz and biotite, were investigated in Grimsel groundwater simulant in a large Se concentration range (from $1.66 \times 10^{-10} \mathrm{M}$ to $1 \times 10^{-3} \mathrm{M}$ ). Experimental results show that the distribution coefficients ( $\mathrm{K}_{\mathrm{d}}$ values) of $\mathrm{Se}(\mathrm{IV})$ on the rock and mineral samples increased with the decreasing of $\mathrm{Se}(\mathrm{IV})$ concentration. The sorption of $\mathrm{Se}(\mathrm{IV})$ on biotite has the largest $\mathrm{K}_{\mathrm{d}}$ value in low concentration area $\left(<10^{-7} \mathrm{M}\right)$ stabilizing between $0.0595 \pm 0.0097 \mathrm{~m}^{3} / \mathrm{Kg}$ and $0.0713 \pm 0.0164 \mathrm{~m}^{3} / \mathrm{Kg}$. The $\mathrm{K}_{\mathrm{d}}$ value of $\mathrm{Se}(\mathrm{IV})$ on $\mathrm{K}$-feldspar was the second largest $\left(0.0154 \pm 0.0019 \mathrm{~m}^{3} / \mathrm{Kg}\right.$ in $\left.10^{-9} \mathrm{M}\right)$ while the sorption on quartz was negligible. The sorption behavior of Se(IV) on Grimsel granodiorite followed the same trend as plagioclase, the most abundant mineral in Grimsel granodiorite, with $\mathrm{K}_{\mathrm{d}}$ values of $0.0078 \pm 0.0010 \mathrm{~m}^{3} / \mathrm{Kg}$ for Grimsel granodiorite and $0.0085 \pm 0.0016 \mathrm{~m}^{3} / \mathrm{Kg}$ for plagioclase, when Se(IV) concentration was $10^{-9}$ M. HPLC-ICP-MS results show that all the Se(IV)

$\begin{array}{lll}\text { Author } & \text { Title } & \text { File Name } \\ \text { Xiaodong Li et al. } & \begin{array}{l}\text { Sorption of Se species on mineral surfaces, Part I: Batch sorption and } \\ \text { multi-site modelling }\end{array} & \begin{array}{l}\text { Xiaodong_et_al__ } \\ \text { manuscript }\end{array}\end{array}$


remained in +IV oxidation state after more than 1 month experimental time and speciation modelling proved that the main species in Grimsel groundwater simulant were $\mathrm{HSeO}_{3}{ }^{-}$and $\mathrm{SeO}_{3}{ }^{2-}$. Multisite surface complexation modelling was performed by PHREEQC with the help of molecular modelling techniques which was performed with the CASTEP code implemented into Materials Studio. The modelling results predict that there are three kinds of sorption sites on the surface of biotite mineral, with sorption site densities differing in three magnitudes.

Keywords: selenium, sorption, crystalline rock, minerals, surface complexation modelling

\section{Introduction}

The disposal of high-level nuclear waste and spent nuclear fuel is an indispensable part of the whole nuclear fuel cycle and plays an important role in nuclear waste safety. The final disposal of spent nuclear fuel is considered to take place in deep geological repositories which is surrounded by bedrock (Posiva Oy, 2012; Svensk Kärnbränslehantering AB, 2013). The disposal plan of Posiva, the implementing organization for the final disposal of spent nuclear fuel in Finland, is based on the KBS-3 concept which includes several engineering barriers that are designed to isolate the harmful radionuclides for 100,000 years. The final barrier is the surrounded bedrock and it is believed to provide the retardation of radionuclides from migrating into the groundwater system in case there is a release of radionuclides from the repository (Poteri et al., 2014).

Selenium, namely Se-79, is one of the radionuclides that need great concern when thinking about the long-term safety of radioactive waste repository (Ewing, 2015). The most significant processes of delaying radionuclides flowing through bedrock fractures are diffusion into rock matrix and sorption onto the mineral surfaces (Ewing, 2015; Grisak and Pickens, 1980; Neretnieks, 1980; Séby et al., 1998). Selenium, usually in $\mathrm{Se}(\mathrm{IV})$ and $\mathrm{Se}(\mathrm{VI})$ forms in natural conditions, is a highly mobile

$\begin{array}{lll}\text { Author } & \text { Title } & \text { File Name } \\ \text { Xiaodong Li et al. } & \begin{array}{l}\text { Sorption of Se species on mineral surfaces, Part I: Batch sorption and } \\ \text { multi-site modelling }\end{array} & \begin{array}{l}\text { Xiaodong_et_al_ } \\ \text { manuscript }\end{array}\end{array}$


element without much sorption onto the mineral surfaces (Lehto and Hou, 2011b). Sorption of selenium in these two oxidation states is known to be strong only on aluminum and iron minerals, such as goethite, hematite and pyrite, through surface complexation reactions (Boult et al., 1998; Duc et al., 2003). In addition, the half-life of Se-79 is $3.7 * 10^{5}$ years which makes it a radionuclide that has a high impact on the cumulative radioactive dose in a spent nuclear fuel repository and need great concern for a long time (Atwood, 2010; Lehto and Hou, 2011b).

Selenate $\left(\mathrm{SeO}_{4}{ }^{2-}\right)$ or $\mathrm{Se}(\mathrm{VI})$ dominates the selenium species under oxic conditions (Lehto and Hou, 2011b). Selenate sorption on minerals surfaces usually occurs as weakly-bounded outer sphere mechanism (De Cannière et al., 2010) and the distribution coefficient of selenium is much lower than that of the other radionuclides found in spent nuclear fuel like Cs (Muuri et al., 2017; Söderlund et al., 2016a; Tsai et al., 2009), Ba (Muuri, 2015) and Sr (Eikenberg et al., 1994; Vilks and Degueldre, 1991). At lower redox conditions, selenium is found to be in oxidation state +IV and the dominant species in this oxidation state is selenite $\left(\mathrm{SeO}_{3}{ }^{2-}\right)$ and biselenite $\left(\mathrm{HSeO}_{3}{ }^{-}\right)$; in both species as $\mathrm{Se}(\mathrm{IV})$. The sorption mechanism under this state is studied to be inner sphere complexation where a direct chemical bond is formed between oxygen atom from oxyanion and structural surface metal atom. $\mathrm{HSeO}_{3}{ }^{-}$is more favorable than $\mathrm{SeO}_{3}{ }^{2-}$ when sorbing on the mineral surfaces because the sorption reaction is proposed to proceed as a nucleophilic $\mathrm{S}_{\mathrm{N} 2}$-i-substitution, where a hydrogen bond is formed between the surface $-\mathrm{OH}$ group and hydrogen of the $\mathrm{HSeO}^{-}$ion. In the mechanism, free electron pair on oxyanion's oxygen is attracted towards surface metal cation and $\mathrm{OH}\left(\right.$ or $\mathrm{H}_{2} \mathrm{O}$ ) ligand is cleaved from the surface metal (De Cannière et al., 2010). A new chemical bond with covalent nature is formed between surface metal and oxyanion's oxygen atom. Under intermediate redox potentials (approximately $+200 \mathrm{mV}$ ) both $\mathrm{Se}(\mathrm{IV})$ and $\mathrm{Se}(\mathrm{VI})$ is reduced to elemental selenium. Under lower redox potentials $(\leq+200 \mathrm{mV})$ selenium forms selenide ions $\mathrm{Se}^{2-}$ at oxida-

Author Xiaodong Li et al.
Title

Sorption of Se species on mineral surfaces, Part I: Batch sorption and multi-site modelling

$\begin{array}{lll}\text { File Name } & \text { Date } & \text { Page } \\ \begin{array}{l}\text { Xiaodong_et_al_ } \\ \text { manuscript }\end{array} & 08.12 .2019 & 3(43)\end{array}$


tion state -II (Lehto and Hou, 2011a). The reduction reaction is slow and kinetically hindered because it involves the transfer of multiple electrons along with multiple oxygen atoms between its various oxidation states (VI, IV, 0, -I, -II) (De Cannière et al., 2010; Grambow, 2008; Séby et al., 1998). However, thermodynamic calculations show that selenium exists also at lower oxidation states 0 and -II due to contact with the iron canisters that the nuclear waste is contained in (Altmann, 2008).

In addition to extensive research about matrix diffusion and mineral surface sorption studies performed in laboratories, in recent years, the in-situ experiments, have also been employed to obtain information about the retention properties of crystalline rock in the bedrock conditions (Vilks et al., 2003; Widestrand et al., 2007; Widestrand et al., 2010). For example, the Swiss National Cooperative for Disposal of Radioactive Waste (Nagra) has performed extensive in-situ experiments at the Grimsel test site (GTS) in the Swiss Alps. The second Long Term Diffusion (LTD) experiment was started in spring 2014 using radionuclides $\mathrm{H}-3$, Na-22, Cs-134, Cl-36 and Ba-133 as well as nonradioactive selenium. Grimsel granodiorite is one of the main rock types at the Grimsel test site (GTS) and it has been studied extensively in both in-situ and laboratory conditions (Ikonen et al., 2016a; Ikonen et al., 2016b; Jokelainen et al., 2013; Soler et al., 2015).

Biotite, which is a sheet silicate mineral, is one of the main minerals of Grimsel granodiorite and plays an important role in the sorption and migration of radionuclides in the Grimsel granodiorite rock. The sorption mechanisms have been studied by many researchers before and the suggestions of ion exchange (Kyllönen et al., 2014; Muuri et al., 2016; Muuri et al., 2017) and surface complexation (Chakraborty et al., 2007; Iida et al., 2013; Tsai et al., 2009) are the most probable mechanisms. The sorption of selenium oxyanions might happen onto different sorption sites: the outermost basal planes for cation exchange reactions and the amphoteric edge sites (strong and weak si-

$\begin{array}{lll}\text { Author } & \text { Title } & \text { File Name } \\ \text { Xiaodong Li et al. } & \begin{array}{l}\text { Sorption of Se species on mineral surfaces, Part I: Batch sorption and } \\ \text { multi-site modelling }\end{array} & \begin{array}{l}\text { Xiaodong_et_al_ } \\ \text { manuscript }\end{array}\end{array}$


tes) for surface complexation reactions (Söderlund, 2016). The amphoteric edge sites can be protonated or deprotonated and provide an additional $\mathrm{pH}$-dependent contribution to the surface charge. In minerals or rocks, surface complexation at amphoteric SOH sites is expected to be the most relevant sorption process for anions like selenite (Bradbury and Baeyens, 1995).

The aim of this work is to determine the distribution coefficients of selenite on crushed Grimsel granodiorite and its main minerals over a broad concentration range $\left(10^{-10} \mathrm{M}-10^{-3} \mathrm{M}\right)$ with batch sorption method. The results of batch sorption of selenite provide data for modelling with PHREEQC which is one of the most widely used geochemical modelling code, particularly useful in modelling the sorption of tracer metals on minerals. Furthermore, the results of batch sorption experiments and surface complexation modelling could be used to compare and interpret the migration behavior of selenium in the in-situ experiments carried out in the underground laboratory at Grimsel test site in Switzerland.

\section{Materials and methods}

\subsection{Materials}

The Grimsel granodiorite used in our work was provided by an underground research laboratory in Grimsel test site, Switzerland. It is a medium grained and slightly foliated granite. The main minerals, according to the results of XRD analysis (see section 2.2), are plagioclase (40\%), potassium feldspar (25\%), quartz (20\%) and biotite (10\%). Chlorite, green amphibole (hornblende), muscovite, epidote, titanite and opaque minerals are existing accessory minerals; the percentage of this remaining part is less than 5\% (Ikonen et al., 2016b). The porosity of Grimsel granodiorite varies from $0.5 \%$ to $1.5 \%$ (Kelokaski et al., 2006) and permeability is $(1.3 \pm 0.3) \times 10^{-17} \mathrm{~m}^{2}$ (Ikonen et al., 2016b).

Author

Title

File Name

Date

Page

Xiaodong Li et al.

Sorption of Se species on mineral surfaces, Part I: Batch sorption and multi-site modelling

Xiaodong_et_al_ $08.12 .2019 \quad 5(43)$ manuscript 
The main minerals, plagioclase, biotite and K-feldspar, were provided by the Geological Survey of Finland. Quartz used in this work was bought from UKGE, a geological and expedition supplier in UK.

The Grimsel granodiorite rock sample and the main minerals were crushed by milling after which the crushed samples were sieved. The part with grain sizes between $0.075 \mathrm{~mm}$ and $0.3 \mathrm{~mm}$ was used for mineral characterization (XRD), specific surface area (SSA) and cation exchange capacities (CEC) as well as the batch sorption experiments.

Both stable selenium and radioactive selenium used in the batch sorption experiments were in oxidation state $+\mathrm{IV}$, in $\mathrm{Na}_{2} \mathrm{SeO}_{3}$ and $\mathrm{Na}_{2}{ }^{75} \mathrm{SeO}_{3}$ form, respectively. The radioactive selenium was produced by Czech Metrology Institute with gamma radionuclide impurities less than $0.1 \%$. The stable selenium was a product from SIGMA with $>99 \%$ purity. Though the stable and radioactive selenium are different nuclides, we assume that the sorption properties of them on minerals are close to each other.

A laboratory prepared Grimsel groundwater simulant (GGWS) which was used in this work was prepared using roughly the elemental composition of fracture water in Grimsel test site (Eikenberg et al., 1994; Hoehn et al., 1998; Mäder et al., 2006), based on Labtium groundwater analysis of Grimsel granodiorite water BOAU83.019 \& LTD WP1 reference water (Eikenberg et al., 1994; Hoehn et al., 1998; Mäder et al., 2006). Table 1 presents the elemental compositions of the simulated groundwater and the fracture water from references (Eikenberg et al., 1994; Hoehn et al., 1998; Mäder et al., 2006). Most of the elemental concentrations of GGWS are similar with that measured in the Grimsel test site, except that $\mathrm{Na}^{+}$concentration is a little higher because of the preparation method of the simulated water. One thing should be mentioned is that the $\mathrm{pH}$ of the fresh prepared GGWS was 9.5, but the $\mathrm{pH}$ decreased in about two weeks to around 7.7 after being in equilibrium with the atmospheric $\mathrm{CO}_{2}$. The $\mathrm{pH}$ was not buffered in the batch sorption experiments, thus the $\mathrm{pH}$

\begin{tabular}{|c|c|c|c|c|}
\hline Author & Title & File Name & Date & Page \\
\hline Xiaodong Li et al. & $\begin{array}{l}\text { Sorption of Se species on mineral surfaces, Part I: Batch sorption and } \\
\text { multi-site modelling }\end{array}$ & $\begin{array}{l}\text { Xiaodong_et_al_ } \\
\text { manuscript }\end{array}$ & 08.12.2019 & $6(43)$ \\
\hline
\end{tabular}


of GGWS will change after equilibrium reached between GGWS and Grimsel granodiorite and the main minerals. The reason of the $\mathrm{pH}$ changes will be explained in the section of 3.1 .

Table 1. The elemental composition of Grimsel groundwater and its simulant which was made to resemble the groundwater from the shear zone in GTS.

\begin{tabular}{|c|c|c|c|c|c|c|c|c|c|c|c|}
\hline & $\mathrm{pH}$ & $\mathrm{Na}^{+}$ & $\mathrm{K}^{+}$ & $\mathrm{Ca}^{2+}$ & $\mathrm{Mg}^{2+}$ & $\mathrm{HCO}_{3}^{-}$ & $\mathrm{Cl}^{-}$ & $\mathrm{SO}_{4}^{2-}$ & $\mathrm{Br}^{-}$ & $\mathrm{F}^{-}$ & $\mathrm{Si}^{* *}$ \\
\hline $\begin{array}{c}\text { Grimsel wa- } \\
\operatorname{ter}(\mathrm{mg} / \mathrm{L})\end{array}$ & 9.7 & 15.87 & 0.195 & 5.60 & 0.015 & 27.45 & 5.67 & 5.86 & 0.03 & 6.84 & 7.00 \\
\hline GGWS(mg/L) & $9.5^{*}$ & 25.53 & 0.195 & 5.60 & --- & 27.45 & 5.67 & 5.76 & --- & 6.84 & 7.00 \\
\hline
\end{tabular}

* The $\mathrm{pH}$ decreased to around 7.7 after contacting with air in about 2 weeks.

** $\mathrm{Si}$ was added in form of $\mathrm{Na}_{2} \mathrm{SiO}_{3} \cdot \mathrm{H}_{2} \mathrm{O}$, but the concentration was calculated based on the weight of element Si.

\subsection{Characterization of Grimsel granodiorite and the main minerals}

Mineral composition analysis of Grimsel granodiorite and the main minerals were done by XRD method (performed at the Geological Survey of Finland). The crushed samples were air dried to constant weight before measuring and the grain sizes used were between $0.075 \mathrm{~mm}$ and $0.3 \mathrm{~mm}$. XRD spectra were recorded at an angle interval of $2-70^{\circ} 2 \theta$ with a step size of $0.02^{\circ}$. The time per step was 1s (Söderlund et al., 2015).

Specific surface area measurement of Grimsel granodiorite and the main minerals were determined at Chalmers University with Kr-BET method using gas adsorption analyzing instrument (Micromeritics ASAP 2020) (Muuri et al., 2016). The samples were kept in a vacuum oven at room temperature until constant weight before measuring (the drying time was about 1 month).

Author

Xiaodong Li et al.
Title

Sorption of Se species on mineral surfaces, Part I: Batch sorption and multi-site modelling

$\begin{array}{lll}\text { File Name } & \text { Date } & \text { Page } \\ \begin{array}{l}\text { Xiaodong_et_al_ } \\ \text { manuscript }\end{array} & \text { 08.12.2019 } & 7(43)\end{array}$


The cation exchange capacities of all the samples were determined by extracting crushed samples with $1 \mathrm{M}$ ammonium acetate $\left(\mathrm{NH}_{4} \mathrm{Ac}\right)$ which can buffer the $\mathrm{pH}$ of the solutions contacting with different minerals at about pH 7 (Ciesielski et al., 1997; Lahdenperä, 2009). The solid to liquid ratio is $100 \mathrm{~g} / \mathrm{L}$. After extracting the samples for two hours, the mixtures were centrifuged immediately at $3000 \mathrm{r} / \mathrm{s}$ for 15 minutes. After that $5 \mathrm{~mL}$ of supernatants were taken and measured by using Microwave Plasma Atomic Emission Spectroscopy (MP-AES, model: MP4100). The CEC was determined as a sum of concentrations of base cations $\left(\mathrm{Ca}^{2+}, \mathrm{Mg}^{2+}, \mathrm{Na}^{+}, \mathrm{K}^{+}\right)$and aluminum $\left(\mathrm{Al}^{3+}\right)$, manganese $\left(\mathrm{Mn}^{2+}\right)$ and iron $\left(\mathrm{Fe}^{3+}\right)$.

\subsection{Batch sorption experiments}

The batch sorption experiments were carried out under atmospheric conditions and room temperature $(22 \pm 3){ }^{\circ} \mathrm{C}$. The purpose was to obtain the sorption isotherms of selenium on Grimsel granodiorite rock sample and its main minerals with a broad selenium concentration range between $1.66 \times 10^{-10} \mathrm{M}$ to $10^{-3} \mathrm{M}$. These concentrations were chosen because the levels of selenium concentration range from $0.06 \mu \mathrm{g} / \mathrm{L}\left(7.7 \times 10^{-10} \mathrm{M}\right)$ to about $400 \mu \mathrm{g} / \mathrm{L}\left(5.1 \times 10^{-6} \mathrm{M}\right)$ in groundwaters (Linberg, 1968; Scott and Voegeli, 1961; Smith and Westfall, 1937; World Health Organization, 2011).

The batch sorption experiments were conducted using crushed and air-dried Grimsel granodiorite rock sample and its main minerals with the grain sizes of each between $0.075 \mathrm{~mm}$ and $0.3 \mathrm{~mm}$. The amount of rock and mineral sample and groundwater simulant were $0.5 \mathrm{~g}$ and $10 \mathrm{~mL}$, respectively, with their ratio being $50 \mathrm{~g} / \mathrm{L}$. They were mixed in $20 \mathrm{~mL}$ polyethylene bottles. First, the crushed rock samples and GGWS were left to stabilize 2 weeks in a shaker in order to obtain a natural equilibrium between the GGWS and minerals. Triplicate samples were conducted for each sample. Two weeks time was believed to be long enough for the rock samples to be saturated with groundwater

$\begin{array}{lll}\text { Author } & \text { Title } & \text { File Name } \\ \text { Xiaodong Li et al. } & \begin{array}{l}\text { Sorption of Se species on mineral surfaces, Part I: Batch sorption and } \\ \text { multi-site modelling }\end{array} & \begin{array}{l}\text { Xiaodong_et_al_ } \\ \text { manuscript }\end{array}\end{array}$


simulant and establish the equilibrium (Ikonen et al., 2016b; Muuri, 2015; Muuri et al., 2016; Muuri et al., 2017). After stabilization period, the $\mathrm{pH}$ value in each sample was measured to record the $\mathrm{pH}$ change of groundwater simulant during equilibration with rock samples.

The batch sorption experiments were conducted in two different ways after the stabilization process according to the detection limit of Se by two different analysis methods, the inductively coupled plasma mass spectrometry (ICP-MS) and radioactive method by using Se-75. The detection limit of ICP-MS with an Octopole reaction system (Agilent 7500ce) was $0.6 \mathrm{ppb}$ which equals to $8 \times 10^{-9} \mathrm{M}$, while the detection limit of radioactive ${ }^{75}$ Se measured by using a Hidex AMG automatic gamma counter (Hidex AMG) is $1.5 \times 10^{-13} \mathrm{M}$. Thus, two kinds of Se tracers were used in the experiments, namely non-radioactive Se and radioactive ${ }^{75} \mathrm{Se}$. For the experiments with Se concentration exceeding $10^{-7} \mathrm{M}$, non-radioactive sodium selenite $\left(\mathrm{Na}_{2} \mathrm{SeO}_{3}\right.$, Sigma-Aldrich) was used as a tracer and the Se concentration was measured using ICP-MS. For the Se concentration $<10^{-7} \mathrm{M}$, the nonradioactive $\mathrm{Se}(\mathrm{IV})$ was added to the samples together with a radiotracer, $\mathrm{Na}_{2}{ }^{75} \mathrm{SeO}_{3}$ and the radioactivity of ${ }^{75} \mathrm{Se}$ was measured by Hidex AMG. The amount of radiotracer added was set to be 528 $\mathrm{Bq} / 10 \mathrm{~mL}$, corresponding to be $1.66 \times 10^{-10} \mathrm{M}$. The whole concentration of Se (stable + radioactive) in the low concentration area ranged from $1.66 \times 10^{-10} \mathrm{M}$ to $1.0 \times 10^{-7} \mathrm{M}$.

After the addition of stable Se or Se-75, the bottles were again agitated for 2 weeks. The samples were then centrifuged and aliquots of sample solutions were filtered with $0.45 \mu$ m polypropylene membrane filters for analysis. The measurement with ICP-MS was done according to ${ }^{82} \mathrm{Se}$ isotope. Quantification of selenium was done using external calibration. Radioactive ${ }^{75} \mathrm{Se}$ was measured by using Hidex AMG by counting the gamma rays of ${ }^{75} \mathrm{Se}$ in $8 \mathrm{~mL}$ groundwater simulant. The counting time was set to be $30 \mathrm{~min}$.

Distribution coefficient $\mathrm{K}_{\mathrm{d}}$ of stable selenium can be determined as follows,

Author

Xiaodong Li et al.
Title

Sorption of Se species on mineral surfaces, Part I: Batch sorption and multi-site modelling

$\begin{array}{lll}\text { File Name } & \text { Date } & \text { Page } \\ \begin{array}{l}\text { Xiaodong_et_al_ } \\ \text { manuscript }\end{array} & \text { 08.12.2019 } & 9(43)\end{array}$




$$
K_{d}=\frac{[S e]_{0}-[S e]}{[S e]} \times \frac{V}{m}
$$

where $[\mathrm{Se}]_{0}$ is the initial concentration of stable selenium in the solution and [Se] the final concentration of selenium in the groundwater simulant. $\mathrm{V}$ is the volume of solution and $\mathrm{m}$ the mass of the solid phase.

For the experiments with radioactive tracer, the distribution coefficients $K_{d}$ were calculated from the activity difference between the blank sample and investigated samples,

$$
K_{d}=\frac{[S e]_{\text {blank }}-[S e]}{[S e]} \times \frac{V}{m}
$$

where $[\mathrm{Se}]_{\text {blank }}$ is the selenium concentration deduced from the activity of ${ }^{75} \mathrm{Se}$ in blank samples (without rock minerals) and [Se] is the selenium concentration that was deduced from the activity of

${ }^{75} \mathrm{Se}$ in groundwater simulant with rock samples.

\subsection{Speciation of selenium}

High-performance liquid chromatography connected to an inductively coupled plasma mass spectrometry (HPLC-ICP-MS; Agilent 1260 Infinity and Agilent 7500 ce) was used in the speciation analysis of selenium before and after batch sorption experiments (Söderlund et al., 2016a; Söderlund et al., 2016b). Dionex AG11 guard column (i.d. 4×length $50 \mathrm{~mm}$ ) and AS11 anion exchange column (i.d. $4 \times$ length $250 \mathrm{~mm}$ ) connected to the HPLC instrument were used in the separation between the anionic selenium species. The ICP-MS instrument acted as a concentration detector. The coupling of chromatography and mass spectrometer was achieved through direct connection by a polyetheretherketone (PEEK) tube between the column and nebulizer. Rhodium $\left({ }^{45} \mathrm{Rh}\right)$ was used as an internal standard by mixing it continuously to the eluent flow through a $\mathrm{T}$-junction

\begin{tabular}{|c|c|c|c|c|}
\hline Author & Title & File Name & Date & Page \\
\hline Xiaodong Li et a & $\begin{array}{l}\text { Sorption of Se species on mineral surfaces, Part I: Batch sorption and } \\
\text { multi-site modelling }\end{array}$ & $\begin{array}{l}\text { Xiaodong_et_al_ } \\
\text { manuscript }\end{array}$ & 08.12 .2019 & $10(43)$ \\
\hline
\end{tabular}
situated between the column and the nebulizer. The total measurement time applied was 8.00 min 
and selenite and selenate peaks were detected at $3.47 \mathrm{~min}$ and $5.55 \mathrm{~min}$ respectively. $10 \mathrm{mM}$ sodium hydroxide $(\mathrm{NaOH})$ was used as an eluent which was bubbled with argon gas throughout the measurements to remove dissolved carbon dioxide from the solution. The flow rate of the eluent was $0.8 \mathrm{~mL} / \mathrm{min}$.

Further interpretation of sorption data and modelling requires the calculations of individual species existing in the GGWS under the conditions of sorption experiments. The PHREEQC code and the Thermoddemv 1.10 database was used to calculation the selenium speciation as a function of $\mathrm{pH}$ in a given initial concentration of $[\mathrm{Se}]_{\mathrm{tot}}=1 \times 10^{-6} \mathrm{~mol} / \mathrm{L}$. The main speciation reactions and their equilibrium constants are given in Table 2.

Table 2. Expected reactions of selenium in GGWS groundwater and their thermodynamic equilibrium constants used in speciation calculations.

\begin{tabular}{ccc}
\hline Speciation reaction & Log $\mathrm{K}$ & Reference \\
\hline $\mathrm{H}^{+}+\mathrm{HSe}^{-}=\mathrm{H}_{2} \mathrm{Se}$ & 3.8 & (ANDRA, 2009; Ervanne et al., 2016) \\
$\mathrm{HSe}^{-}=\mathrm{Se}^{2-}+\mathrm{H}^{+}$ & -14 & (ANDRA, 2009; Ervanne et al., 2016) \\
$\mathrm{H}^{+}+\mathrm{SeO}_{3}{ }^{2-}=\mathrm{HSeO}_{3}^{-}$ & 8.54 & (ANDRA, 2009; Ervanne et al., 2016) \\
$2 \mathrm{H}^{+}+\mathrm{SeO}_{3}{ }^{2-}=\mathrm{H}_{2} \mathrm{SeO}_{3}$ & 11.24 & (ANDRA, 2009; Ervanne et al., 2016) \\
$\mathrm{H}^{+}+\mathrm{SeO}_{4}{ }^{2-}=\mathrm{HSeO}_{4}^{-}$ & 1.8 & (ANDRA, 2009; Ervanne et al., 2016) \\
$2 \mathrm{H}^{+}+\mathrm{SeO}_{4}{ }^{2-}=\mathrm{H}_{2} \mathrm{SeO}_{4}$ & -0.21 & (ANDRA, 2009; Ervanne et al., 2016) \\
$\mathrm{Ca}^{2+}+\mathrm{SeO}_{4}{ }^{2-}=\mathrm{CaSeO}_{4}$ & 2 & (ANDRA, 2009; Ervanne et al., 2016) \\
$\mathrm{Mg}^{2+}+\mathrm{SeO}_{4}{ }^{2-}=\mathrm{MgSeO}_{4}$ & 2.2 & (ANDRA, 2009; Ervanne et al., 2016) \\
\hline
\end{tabular}




\subsection{Isotherm equations and surface complexation modelling}

\subsubsection{Isotherm equations}

Two widely used equilibrium isotherm models which are used to describe sorption equilibrium over two heterogeneous systems were tested in this work, the Freundlich isotherm equation and the Langmuir isotherm equation. The Freundlich isotherm model is the earliest known relationship describing the non-ideal and reversible adsorption, not restricted to the formation of monolayer. This empirical model can be applied to multilayer adsorption, with non-uniform distribution of adsorption heat and affinities over the heterogeneous surfaces. At present, Freundlich isotherm has been widely applied to many heterogeneous systems. The slope that ranges between 0 and 1 is a measure of adsorption intensity or surface heterogeneity; system becoming more heterogeneous as its value gets closer to zero. In addition, the exponent above one is an indicative of cooperative adsorption.

The amount of selenium sorbed on crushed samples, $\Gamma(\mathrm{mol} / \mathrm{Kg})$ and the concentration of selenium remained in supernatant (GGWS in the experiments), $\mathrm{C}$ (mol/L) can be described with Freundlich equation (Freundlich et al., 1909) as,

$$
\Gamma=K_{f} C^{n}
$$

where $\mathrm{K}_{\mathrm{f}}(\mathrm{L} / \mathrm{Kg})$ and $\mathrm{n}$ are adjustable coefficients. For fitting of experimental data, the Freundlich equation can be linearized by a log transform to:

$$
\log \Gamma=\log K_{f}+n \log C
$$

which enables the constants to be derived by linear regression.

The Langmuir equation (Langmuir, 1918) has a better theoretical background and its form can be

\begin{tabular}{|c|c|c|c|c|}
\hline Author & Title & File Name & Date & Page \\
\hline Xiaodong Li et al. & $\begin{array}{l}\text { Sorption of Se species on mineral surfaces, Part I: Batch sorption and } \\
\text { multi-site modelling }\end{array}$ & $\begin{array}{l}\text { Xiaodong_et_al_ } \\
\text { manuscript }\end{array}$ & 08.12 .2019 & $12(43)$ \\
\hline
\end{tabular}
expressed as, 


$$
\Gamma=\frac{\Gamma_{\max } K_{a d s} C}{1+K_{a d s} C}
$$

where $\Gamma_{\max }(\mathrm{mol} / \mathrm{Kg})$ is the adsorption maximum and $K_{\text {ads }}(\mathrm{L} / \mathrm{mol})$ is the constant related to the energy of adsorption.

The linearized Langmuir isotherm equation is,

$$
\frac{C}{\Gamma}=\frac{C}{\Gamma_{\max }}+\frac{1}{K_{a d s} \Gamma_{\max }}
$$

Fitting of experimental data will enable the parameters to be derived by linear regression.

\subsubsection{Surface complexation modelling}

For anions, like selenite, the dominating procedure of the sorption process is surface complexation. In this study, the selenite sorption process on biotite was simulated by using PHREEQC, a computer program that is designed to perform a wide variety of aqueous geochemical calculations like speciation, sorption reactions, one-dimensional (1D) transport and inverse geochemical calculations. The Dzombak and Morel's Diffuse Double Layer model (DDL) was used to describe the sorption of selenite onto biotite surface as a function of selenite concentration from $10^{-10} \mathrm{M}$ to $10^{-3}$ M. The Thermoddemv 1.10 database, which was also used in the speciation modelling as mentioned above, was used for the thermodynamic calculations.

The hydrated biotite surface is described by two amphoteric surface reactive site types in terms of protonation

$$
\mathrm{S} \_\mathrm{OH}+\mathrm{H}^{+} \rightleftharpoons \mathrm{S} \_\mathrm{OH}_{2}^{+} \quad \mathrm{K}_{\mathrm{a} 1}
$$

and deprotonation

$$
\mathrm{S} \_\mathrm{OH} \rightleftharpoons \mathrm{S} \_\mathrm{O}^{-}+\mathrm{H}^{+} \quad \mathrm{K}_{\mathrm{a} 2}
$$

$\begin{array}{lll}\text { Author } & \text { Title } & \text { File Name } \\ \text { Xiaodong Li et al. } & \begin{array}{l}\text { Sorption of Se species on mineral surfaces, Part I: Batch sorption and } \\ \text { multi-site modelling }\end{array} & \begin{array}{l}\text { Xiaodong_et_al__ 08.12.2019 } \\ \text { manuscript }\end{array}\end{array}$


where S_OH ${ }_{2}^{+}$, S_OH and S_O- represent the positively charged, neutral and negatively charged surface sites. $\mathrm{K}_{\mathrm{a} 1}$ and $\mathrm{K}_{\mathrm{a} 2}$ are the intrinsic equilibrium constants for protolysis reactions and their values are cited from the work done by S. Chakraborty et al. (Chakraborty et al., 2007).

The SSA and CEC values of biotite were characterized in this experiment and these values will be fixed in the modelling process.

The site densities and site types were calculated according to molecular modelling by using quantum mechanics CASTEP (CAmbridge Serial Total Energy Package) code implemented into Materials Studio software. For the modelling of sorption isotherms, at least two kinds of sorption sites are required, the so called strong (S_sOH) and weak sites (S_wOH) (Ervanne et al., 2016; Ervanne et al., 2013; Missana et al., 2009). According to the molecular modelling calculations in the second part of this work (Puhakka et al., 2018), on the surface of biotite, two types of weak sorption sites exist. The first kind of weak site is on the basal biotite (001) surface. The site density of this kind of sorption site, based on the calculations of surface area and maximum coverage, is $3.2 \mathrm{sites} / \mathrm{nm}^{2}$. The second kind of weak site is on the ideal edge (110) surface of biotite. The selenium species is adsorbed on the top of the interlayer which is supposed to be the significant edge position. The site density of this kind of sorption site is about 1.4 sites $/ \mathrm{nm}^{2}$. The sorption onto the strong sites is supposed to happen onto a mineral as a mixture of surface complexes bound to the edge sites of the cis-vacant (cv) and trans-vacant (tv) of Al octahedrons (Dähn et al., 2011). These kinds of reactions happen very slowly and the number of strong sites are rather small. In this work, the site density of strong sorption sites was got from the best fitting of the sorption isotherms. The parameters used in the modelling process are summarized in Table 3.

Table 3. The main parameters used for the PHREEQC modelling of the experimental sorption data.

\begin{tabular}{|c|c|c|c|c|}
\hline Author & Title & File Name & Date & Page \\
\hline Xiaodong Li et al. & $\begin{array}{l}\text { Sorption of Se species on mineral surfaces, Part I: Batch sorption and } \\
\text { multi-site modelling }\end{array}$ & $\begin{array}{l}\text { Xiaodong_et_al_ } \\
\text { manuscript }\end{array}$ & 08.12.2019 & $14(43)$ \\
\hline
\end{tabular}




\begin{tabular}{lll}
\hline Parameter & Value & Reference \\
\hline $\mathrm{CEC}(\mathrm{meq} / \mathrm{Kg})$ & 12.64 & Experimental data \\
$\mathrm{SSA}\left(\mathrm{m}^{2} / \mathrm{g}\right)$ & 1.0323 & Experimental data \\
$\mathrm{S} \_\mathrm{sOH}$ density (sites $\left./ \mathrm{nm}^{2}\right)$ & 0.001 & Adjusted from fit \\
$\mathrm{S} \_\mathrm{wOH}$ density (sites/nm $\left.{ }^{2}\right)$ & 3.2 & (Puhakka et al., 2018) \\
$\mathrm{S} \_\mathrm{wOH}$ density (sites/nm $\left.{ }^{2}\right)$ & 1.4 & (Puhakka et al., 2018) \\
$\log \mathrm{K}_{\mathrm{a} 1}(\mathrm{~s})$ & 5.0 & (Chakraborty et al., 2007) \\
$\log \mathrm{K}_{\mathrm{a} 2}(\mathrm{~s})$ & -6.4 & (Chakraborty et al., 2007) \\
$\log \mathrm{K}_{\mathrm{a} 1}(\mathrm{w})$ & 5.0 & (Chakraborty et al., 2007) \\
$\log \mathrm{K}_{\mathrm{a} 2}(\mathrm{w})$ & -6.4 & (Chakraborty et al., 2007) \\
$\log \mathrm{K}_{\mathrm{a} 1}(\mathrm{ww})$ & 6.0 & Adjusted from fit \\
$\log \mathrm{K}_{\mathrm{a} 2}(\mathrm{ww})$ & -7.4 & Adjusted from fit \\
\hline
\end{tabular}

The modelling of sorption data was carried out supposing the formation of surface complexes at the $\mathrm{SOH}$ sites (both strong and weak sites), of the two main selenium species $\left(\mathrm{HSeO}_{3}{ }^{-}\right.$and $\mathrm{SeO}_{3}{ }^{2-}$ ) observed from the speciation modelling. The surface complexation reactions were considered in the following forms:

$$
\begin{aligned}
& \mathrm{S} \_\mathrm{OH}+\mathrm{SeO}_{3}{ }^{2-} \rightleftharpoons \mathrm{S} \_\mathrm{OHSeO}_{3}{ }^{2-} \\
& \mathrm{S} \_\mathrm{OH}+\mathrm{HSeO}_{3}{ }^{-} \rightleftharpoons \mathrm{S} \_\mathrm{OH}_{2} \mathrm{SeO}_{3}{ }^{-}
\end{aligned}
$$

In addition, the sorption of $\mathrm{SO}_{4}{ }^{2-}$ and $\mathrm{Ca}^{2+}$ were also considered since these two ions exist in large amount in the Grimsel groundwater simulant (Table 1). The main surface reactions with their equi-

\begin{tabular}{|c|c|c|c|c|}
\hline Author & Title & File Name & Date & Page \\
\hline Xiaodong Li et al. & $\begin{array}{l}\text { Sorption of Se species on mineral surfaces, Part I: Batch sorption and } \\
\text { multi-site modelling }\end{array}$ & $\begin{array}{l}\text { Xiaodong_et_al_ } \\
\text { manuscript }\end{array}$ & 08.12 .2019 & $15(43)$ \\
\hline
\end{tabular}
librium constants are given in Table 2 and Table 4. 
Table 4. Surface reactions and equilibrium constants for surface complexation modelling of Se(IV) on biotite.

\begin{tabular}{lll}
\hline Surface reaction & $\log \mathrm{K}$ & Reference \\
\hline $\mathrm{S} \_\mathrm{w}(\mathrm{w}) \mathrm{OH}+\mathrm{SeO}_{3}{ }^{2-} \rightleftharpoons \mathrm{S} \_\mathrm{w}(\mathrm{w}) \mathrm{OHSeO}_{3}{ }^{2-}$ & 2.0 & No influence \\
$\mathrm{S} \_\mathrm{w}(\mathrm{w}) \mathrm{OH}+\mathrm{HSeO}_{3}{ }^{-} \rightleftharpoons \mathrm{S} \_\mathrm{w}(\mathrm{w}) \mathrm{OH}_{2} \mathrm{SeO}_{3}{ }^{-}$ & 4.1 & Adjusted from fit \\
$\mathrm{S} \_\mathrm{sOH}+\mathrm{HSeO}_{3}{ }^{-} \rightleftharpoons \mathrm{S} \_\mathrm{sOH}_{2} \mathrm{SeO}_{3}{ }^{-}$ & 8.93 & Adjusted from fit \\
$\mathrm{S}_{-} \mathrm{sOH}+\mathrm{HSeO}_{3}{ }^{-}+\mathrm{H}^{+}=\mathrm{S} \_\mathrm{sOH}_{2} \mathrm{HSeO}_{3}$ & 10 & No influence \\
$\mathrm{H}^{+}+\mathrm{SO}{ }^{2-}+\mathrm{S}_{-} \mathrm{w}(\mathrm{w}) \mathrm{OH}=\mathrm{S} \_\mathrm{w}(\mathrm{w}) \mathrm{SO}^{-}+\mathrm{H}_{2} \mathrm{O}$ & 7.78 & (ANDRA, 2009) \\
$\mathrm{SO}_{4}{ }^{2-}+\mathrm{S} \_\mathrm{w}(\mathrm{w}) \mathrm{OH}=\mathrm{S} \_\mathrm{w}(\mathrm{w}) \mathrm{OHSO}_{4}{ }^{2-}$ & 0.79 & (ANDRA, 2009) \\
$\mathrm{Ca}^{2+}+\mathrm{S} \_\mathrm{w}(\mathrm{w}) \mathrm{OH}=\mathrm{S} \_\mathrm{w}(\mathrm{w}) \mathrm{OCa}{ }^{+}+\mathrm{H}^{+}$ & -5.58 & (ANDRA, 2009) \\
\hline
\end{tabular}

\section{Results and discussion}

\subsection{Mineral characterization}

The mineral composition of Grimsel granodiorite and the main minerals which was measured by XRD method, are listed in Table 5. The table shows that Grimsel granodiorite is a mixture of several minerals with plagioclase the highest composition (40\%). There is no significant impurities in biotite and quartz used in this experiment but K-feldspar and plagioclase are mixtures of several minerals which is important to take into account when interpreting the selenium sorption results. One should also remember that, XRD method can only identify phases in the crystalline form. As for the

Author

Xiaodong Li et al.
Title

Sorption of Se species on mineral surfaces, Part I: Batch sorption and multi-site modelling

$\begin{array}{lll}\text { File Name } & \text { Date } & \text { Page } \\ \begin{array}{l}\text { Xiaodong_et_al_ } \\ \text { manuscript }\end{array} & 08.12 .2019 & 16(43)\end{array}$


amorphous (non-crystalline) substances that may exist in the minerals, the XRD method cannot determine information. According to the methods described above, the analytical results are based on the concentrations provided by the EVA interception program and the analytical accuracy is semiquantitative (about $\pm 5 \%$ ).

Table 5. Purity analysis of Grimsel granodiorite and its main minerals by using XRD method. The accuracy of the results is about $\pm 5 \%$.

\begin{tabular}{|c|c|}
\hline Rock/mineral & Purity \\
nodiorite & $5 \%$ chlorite \\
\hline Plagioclase & 40\% plagioclase, 25\% K-feldspar, 20\% quartz, 10\% biotite and \\
& chlorite, quartz, magnetite, ilmenite altogether $<10 \%$ \\
\hline Biotite & $100 \%$ \\
\hline Quartz & \\
\hline K-feldspar & \\
\hline
\end{tabular}

Cation exchange capacity (CEC) of the rock and mineral samples (meq/Kg, Table 6) was determined with ammonium acetate solution which can buffer the system at a $\mathrm{pH}$ value around 7.1 by the buffer effect of both $\mathrm{NH}_{4}^{+}$and $\mathrm{Ac}^{-}$ions. The $\mathrm{pH}$ of ammonium acetate solution without adding crushed rock and mineral samples was 7.11 and the $\mathrm{pH}$ values didn't change much after contact with crushed samples. The highest deviation appeared with plagioclase; a slightly higher $\mathrm{pH}$ value

\begin{tabular}{|c|c|c|c|c|}
\hline Author & Title & File Name & Date & Page \\
\hline Xiaodong Li et al. & $\begin{array}{l}\text { Sorption of Se species on mineral surfaces, Part I: Batch sorption and } \\
\text { multi-site modelling }\end{array}$ & $\begin{array}{l}\text { Xiaodong_et_al_ } \\
\text { manuscript }\end{array}$ & 08.12 .2019 & $17(43)$ \\
\hline
\end{tabular}


(7.20) was found. As a comparison, the $\mathrm{pH}$ values of the Grimsel groundwater simulant equilibrated with the crushed samples are also listed in Table 6. The $\mathrm{pH}$ of Grimsel groundwater simulant was 7.68 , but after contact with crushed samples, the $\mathrm{pH}$ changed dramatically because of the exchange of ions between the minerals of the crushed rock and groundwater simulant. The highest $\mathrm{pH}$ value (8.41) was found with crushed plagioclase. The $\mathrm{pH}$ change was modelled by PHREEQC Program and the results show that the $\mathrm{pH}$ changes was mainly caused by two progresses - first the dissolving of elements from minerals which is a $\mathrm{H}^{+}$consuming process and secondly the hydrolysis of $\mathrm{Al}^{3+}$ which is a $\mathrm{H}^{+}$producing process. The final $\mathrm{pH}$ value of the groundwater simulant was mainly determined by the competition of these two processes. For example, the mass balance of the hydrolysis of K-feldspar can be described as,

$$
\mathrm{KAlSi}_{3} \mathrm{O}_{8}+4 \mathrm{H}^{+}=\mathrm{Al}^{3+}+\mathrm{K}^{+}+2 \mathrm{H}_{2} \mathrm{O}+3 \mathrm{SiO}_{2}
$$

The reaction products lead to the following species after released into the solution,

$$
\begin{aligned}
\mathrm{Al}^{3+}+3 \mathrm{OH}^{-} & \rightarrow \mathrm{Al}(\mathrm{OH})_{3} \\
\mathrm{~K}^{+} & \rightarrow \mathrm{K}^{+} \\
3 \mathrm{SiO}_{2} & \rightarrow 3 \mathrm{SiO}_{2}
\end{aligned}
$$

Hence, at least $1 \mathrm{~mol}$ of net amount of $\mathrm{H}^{+}$is consumed by dissolution reactions of $1 \mathrm{~mol}$ of $\mathrm{K}$ feldspar, assuming that all the produced $\mathrm{Al}^{3+}$ will hydrolyse to $\mathrm{Al}(\mathrm{OH})_{3}$. This assumption is realistic

\begin{tabular}{|c|c|c|c|c|}
\hline Sample & $\mathrm{SSA}\left(\mathrm{m}^{2} / \mathrm{g}\right)$ & $\begin{array}{c}\text { CEC } \\
(\mathrm{meq} / \mathrm{Kg})\end{array}$ & 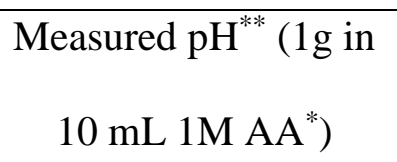 & $\begin{array}{l}\text { Measured } \mathrm{pH}^{* * *}(0.5 \mathrm{~g} \\
\text { in } 10 \mathrm{~mL} \text { groundwater })\end{array}$ \\
\hline Author & Title & & & File Name \\
\hline Xiaodong Li et al. & $\begin{array}{l}\text { Sorption o } \\
\text { multi-site }\end{array}$ & $\begin{array}{l}\text { species on } \mathrm{min} \\
\text { delling }\end{array}$ & surfaces, Part I: Batch sorption & $\begin{array}{l}\text { Xiaodong_et_al_ } \quad 08.12 .2019 \\
\text { manuscript }\end{array}$ \\
\hline
\end{tabular}
since the solubility product of $\mathrm{Al}(\mathrm{OH})_{3}\left(3 \times 10^{-34}\right)$ is quite low, making $\mathrm{Al}^{3+}$ a easily-hydrolysed ion in alkaline solution. The concentration of $\mathrm{Al}^{3+}$ in a solution with $\mathrm{pH} 7.7$ is $3.8 \times 10^{-11} \mathrm{M}$.

Table 6. Chemical and physical characteristics of Grimsel granodiorite and the main minerals. 


\begin{tabular}{|c|c|c|c|c|}
\hline Grimsel & $0.1268(3)$ & $3.32(11)$ & 7.08 & 7.96 \\
\hline Plagioclase & $0.1150(2)$ & $22.69(83)$ & 7.20 & 8.41 \\
\hline Biotite & $1.0323(41)$ & $12.64(42)$ & 7.08 & 7.83 \\
\hline Quartz & $0.0486(2)$ & $0.01(0)$ & 7.05 & 7.87 \\
\hline K-feldspar & $0.1084(5)$ & $1.68(3)$ & 7.05 & 7.77 \\
\hline
\end{tabular}

* AA: ammonium acetate, $\mathrm{NH}_{4} \mathrm{Ac}$

** The $\mathrm{pH}$ value of blank ammonium acetate solution was 7.1.

*** The $\mathrm{pH}$ value of Grimsel groundwater simulant was 7.68 when used in the batch sorption experiment because of the dissolution of $\mathrm{CO}_{2}$ from the air.

The CEC results of all the mineral samples, which were used in the batch sorption experiments and modelling work, are shown in Table 6. Plagioclase (impurities mixture of other minerals shown in table 5) $\left(\mathrm{NaAlSi}_{3} \mathrm{O}_{8}-\mathrm{CaAl}_{2} \mathrm{Si}_{2} \mathrm{O}_{8}\right)$ has the highest $\mathrm{CEC}$ value $(22.69 \pm 0.83 \mathrm{meq} / \mathrm{Kg})$, followed by biotite $\left(\mathrm{K}(\mathrm{Mg}, \mathrm{Fe})_{3}\left(\mathrm{AlSi}_{3} \mathrm{O}_{10}\right)(\mathrm{F}, \mathrm{OH})_{2}\right)$ which has about the half $\mathrm{CEC}$ value of plagioclase $(12.64 \pm 0.42 \mathrm{meq} / \mathrm{Kg})$. The CEC of quartz $\left(\mathrm{SiO}_{2}, 0.01 \mathrm{meq} / \mathrm{Kg}\right)$ can be omitted, which is in accordance with the solid and stable structure of it (see Section 3.3).

The SSA determination results are also shown in Table 6. It shows that biotite has the largest SSA value $\left(1.0323 \pm 0.0041 \mathrm{~m}^{2} / \mathrm{g}\right)$, which is due to the layered sheet structure of it, providing roughness to the surface and large area of inner surface. The SSA of quartz is low $(0.0486 \pm 0.0002$ $\mathrm{m}^{2} / \mathrm{g}$ ), which may indicate that the SSA of quartz is practically composed of outer surface area only (Söderlund et al., 2015). Grimsel granodiorite, plagioclase and K-feldspar have rather similar SSA

Author

Xiaodong Li et al.
Title

Sorption of Se species on mineral surfaces, Part I: Batch sorption and multi-site modelling

$\begin{array}{lll}\text { File Name } & \text { Date } & \text { Page } \\ \begin{array}{l}\text { Xiaodong_et_al__ } \\ \text { manuscript }\end{array} & \text { 88.12.2019 } & 19(43)\end{array}$


values (0.1084(5)-0.1268(3) $\left.\mathrm{m}^{2} / \mathrm{g}\right)$. Considering both SSA and CEC values of all these rock and mineral samples, one can predict that plagioclase and biotite may play important roles in the sorption of different ions like cesium and barium (Muuri et al., 2016; Muuri et al., 2017; Söderlund et al., 2016a), niobium (Söderlund et al., 2015) and selenite (Söderlund et al., 2016b) because of their either large SSA or CEC values.

\subsection{Speciation of selenite and selenate in the sorption experiments}

In the normal atmosphere where the Eh value can be as high as $0.4 \mathrm{~V}$, there is a chance that selenite can be oxidized to selenate according to the Eh-pH diagram (Figure 1) (National Institute of Advanced Industrial Science and Technology et al., 2005). The Eh-pH diagram shows that the experimental environment (Eh between $0.2 \mathrm{~V}$ and $0.4 \mathrm{~V}, \mathrm{pH}$ between 7 and 9) of our work is at the edge of three main selenium species, $\mathrm{HSeO}_{3}{ }^{-}, \mathrm{SeO}_{3}{ }^{2-}$ and $\mathrm{SeO}_{4}{ }^{2-}$. In slightly lower Eh conditions (Eh below $0.4 \mathrm{~V}$ ), $\mathrm{HSeO}_{3}{ }^{-}$and $\mathrm{SeO}_{3}{ }^{2-}$ are the dominant species, but when $\mathrm{pH}$ is more than 8 and $\mathrm{Eh}$ is near $0.4 \mathrm{~V}$, which is the situation in the case of plagioclase where the $\mathrm{pH}$ value was $8.41, \mathrm{SeO}_{4}{ }^{2-}$ species could be formed.

HPLC-ICP-MS was used to separate the species of Se(IV) and Se(VI) and measure the amounts of selenium in both valence states respectively before and after the sorption experiments. The results are shown in Figure 2. A peak was detected at $227 \pm 2$ s when the plagioclase sample was injected into the instrument after one month of experimental time. This represents the existence of Se(IV) (Söderlund et al., 2016b). In order to be sure of the position of Se(VI) peak, a sample that contains only $\mathrm{Na}_{2} \mathrm{SeO}_{4}$ was also tested and the result is also shown in Figure 2 as a dashed line. As we can see, the peak of selenate will appear at $378 \pm 20 \mathrm{~s}$. There is no peak at that point which assures that no detectable amount of selenite was oxidized to selenate during the experimental time since no sign of selenate.

\begin{tabular}{|c|c|c|c|c|}
\hline Author & Title & File Name & Date & Page \\
\hline Xiaodong Li et al. & $\begin{array}{l}\text { Sorption of Se species on mineral surfaces, Part I: Batch sorption and } \\
\text { multi-site modelling }\end{array}$ & $\begin{array}{l}\text { Xiaodong_et_al_ } \\
\text { manuscript }\end{array}$ & 08.12.2019 & $20(43)$ \\
\hline
\end{tabular}


The oxidation of selenite to selenate is believed to be a slow process even if it can be oxidized thermodynamically (Lehto and Hou, 2011c). In a three-year long diffusion experiment done by J. Ikonen et al. (Ikonen et al., 2016b) under the same conditions as this work, $16.3 \pm 0.1 \%$ of selenite was oxidized to selenate in the water contacted with Grimsel granodiorite. In another five year long experiment also done by them, the amount of oxidized selenium was only $3.7 \pm 0.2 \%$ in the block scale diffusion experiment done in Kuru grey granodiorite (Ikonen et al., 2016b).

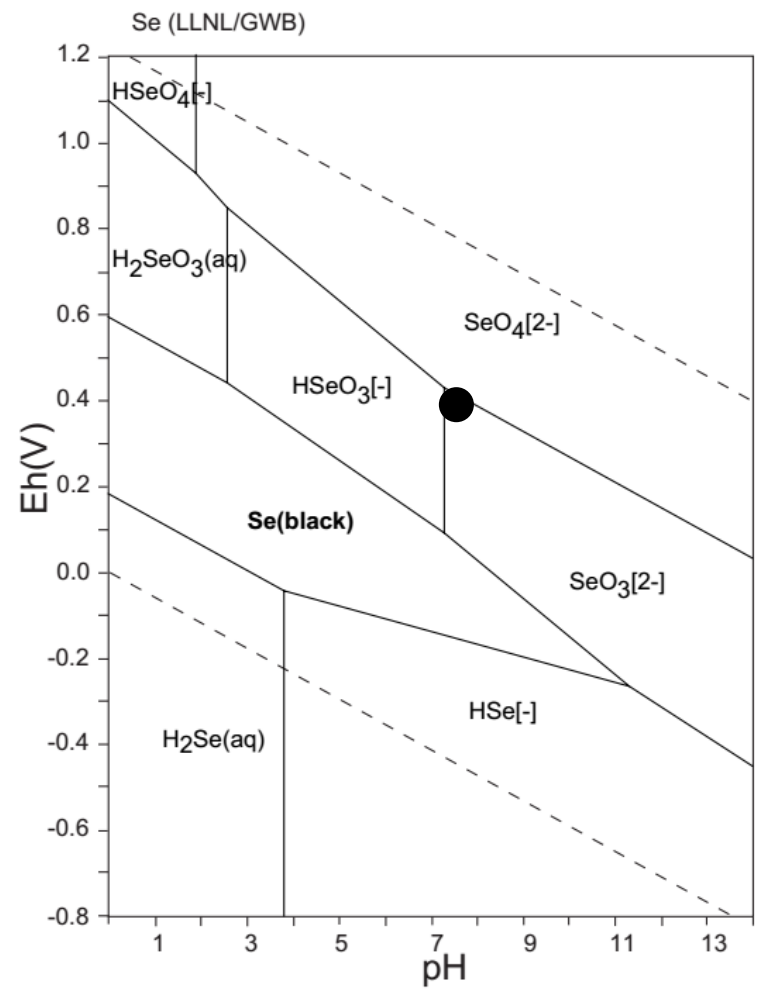

Figure 1. Eh-pH diagram for selenium calculated from the data of Lawrence Livermore National Laboratory (LLNL) (National Institute of Advanced Industrial Science and Technology et al., 2005). The black spot in the figure represents the experimental conditions where the batch sorption experiments were performed. 


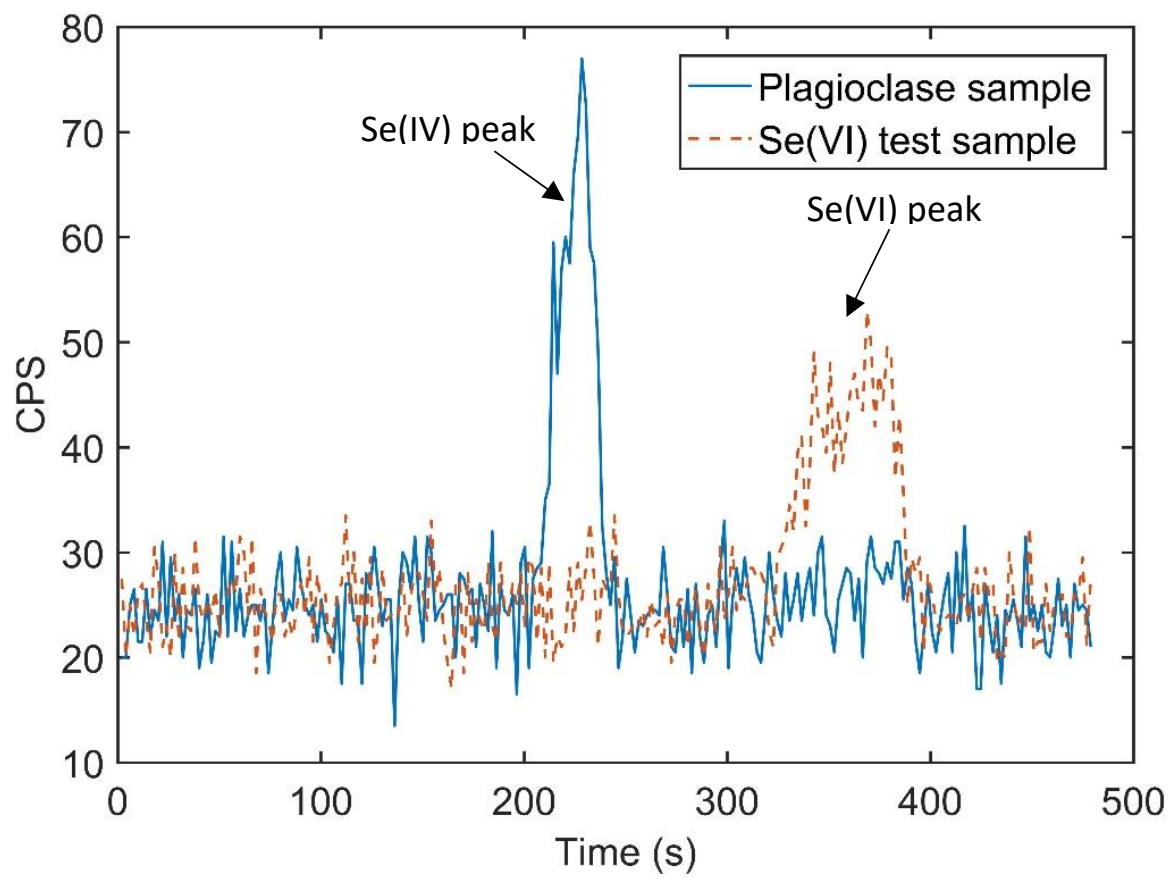

Figure 2. Selenium HPLC-ICP-MS chromatogram of Grimsel groundwater simulant after 1 month stabilization time with crushed plagioclase (solid liquid ratio being $50 \mathrm{~g} / \mathrm{L}$ ) (solid line) and a reference water sample containing $\mathrm{Na}_{2} \mathrm{SeO}_{4}$ only (dashed line) at $10^{-7} \mathrm{~mol} / \mathrm{L}$ concentration level.

Further calculations of the individual species of Se(IV) existing in the Grimsel groundwater under the conditions of sorption experiments were performed with PHREEQC modelling according to the thermodynamic data listed in Table 2 . Figure 3 shows the speciation of Se(IV) calculated as a function of $\mathrm{pH}$ in Grimsel groundwater simulant. The concentration of selenium was set to be $1 \times 10^{-}$ ${ }^{6} \mathrm{M}$. Redox processes were not accounted for in these calculations. $\mathrm{HSeO}_{3}{ }^{-}$is the predominant species when $\mathrm{pH}$ is lower than 8.5 while for a $\mathrm{pH}$ above 8.5 , the main species is $\mathrm{SeO}_{3}{ }^{2-}$. Accounting for the $\mathrm{pH}$ conditions in this work (7.8-8.4), both these two species exist and both will be considered in the following surface complexation modelling process.

Author

Xiaodong Li et al.
Title

Sorption of Se species on mineral surfaces, Part I: Batch sorption and multi-site modelling
File Name Date Page

Xiaodong_et_al_ 08.12.2019 $22(43)$ manuscript 


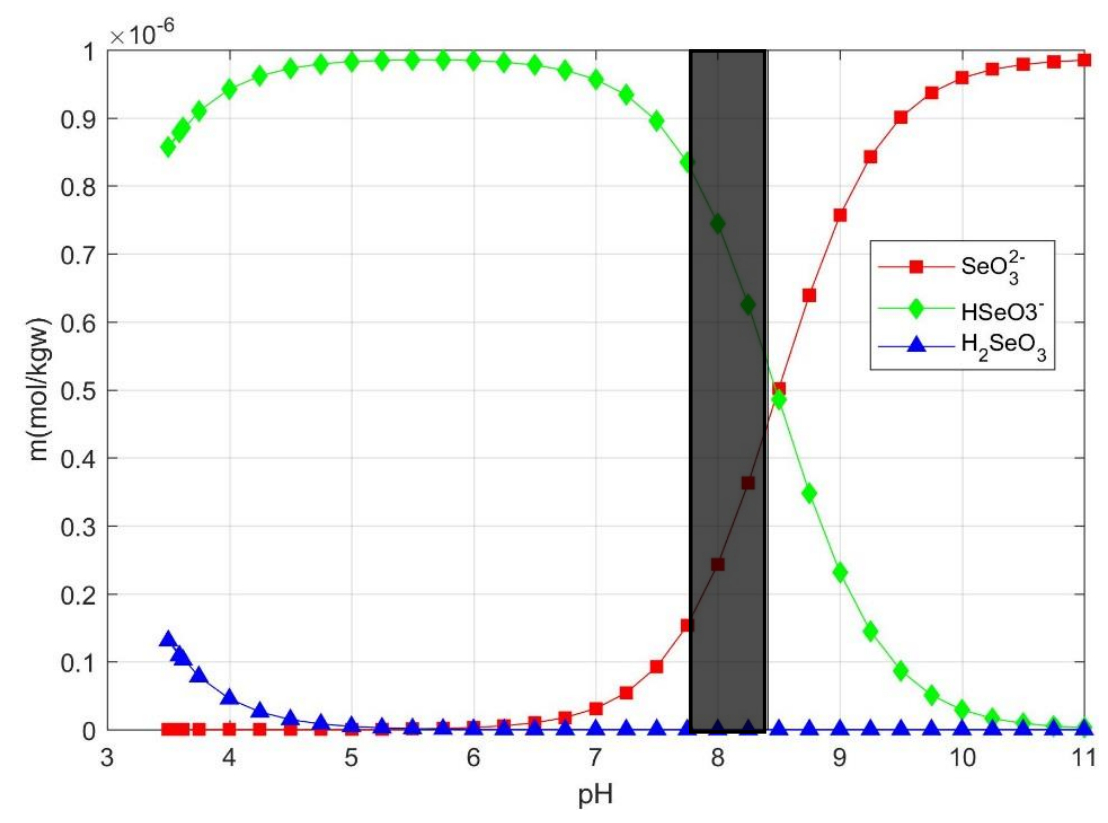

Figure 3. Selenium speciation calculated as a function of the $\mathrm{pH}$ under atmospheric conditions in Grimsel groundwater simulant. The whole concentration of selenium is set to be $1 \times 10^{-6} \mathrm{M}$. The grey area indicates the experimental conditions of batch sorption experiments.

\subsection{Distribution coefficients of selenite on Grimsel granodiorite and the main minerals}

The $K_{d}$ of Se(IV) sorbed on crushed GG and the main minerals are shown in Figure 4 and the results are also listed in Table 7. For nearly all the rock and mineral samples, there is a clear trend that the $K_{d}$ values increase with the decrease of selenite concentration. In the high concentration area $\left(10^{-6} \mathrm{M}\right.$ to $\left.10^{-3} \mathrm{M}\right)$, the $\mathrm{K}_{\mathrm{d}}$ values of all the rock samples remained almost the same, which is caused by insufficiency of free sorption sites. The decrease of $K_{d}$ value at the concentration of $10^{-10} \mathrm{M}$ might have been caused by the release of selenium from biotite. It has been found that the levels of selenium in groundwaters and surface waters, according to a report released by WHO in 2011 , range from $0.06 \mu \mathrm{g} / \mathrm{L}\left(\sim 7.7 \times 10^{-10} \mathrm{M}\right)$ to about $400 \mu \mathrm{g} / \mathrm{L}\left(\sim 5.1 \times 10^{-6} \mathrm{M}\right)$.

The $K_{d}$ of Se(IV) sorption on biotite increased dramatically in the low concentration area $\left(10^{-10}\right.$ $\mathrm{M}$ to $10^{-7} \mathrm{M}$ ), showing that biotite is the most favored mineral for Se(IV) sorption among all the

\begin{tabular}{|c|c|c|c|c|}
\hline Author & Title & File Name & Date & Page \\
\hline Xiaodong Li et al. & $\begin{array}{l}\text { Sorption of Se species on mineral surfaces, Part I: Batch sorption and } \\
\text { multi-site modelling }\end{array}$ & $\begin{array}{l}\text { Xiaodong_et_al_ } \\
\text { manuscript }\end{array}$ & 08.12 .2019 & $23(43)$ \\
\hline
\end{tabular}


main minerals of GG. The $\mathrm{K}_{\mathrm{d}}$ values stabilized between $0.0595 \pm 0.0097 \mathrm{~m}^{3} / \mathrm{Kg}$ and $0.0713 \pm 0.0164$ $\mathrm{m}^{3} / \mathrm{Kg}$ when the concentrations were lower than $10^{-7} \mathrm{M}$. The large amount of sorption on biotite was caused by its sheet structure which results in the distinctively largest SSA among all of the rock samples. It has been observed by E. Muuri et al. that there is a linear trend of the distribution coefficient magnitudes according to the magnitudes of specific surface area (Muuri et al., 2017).
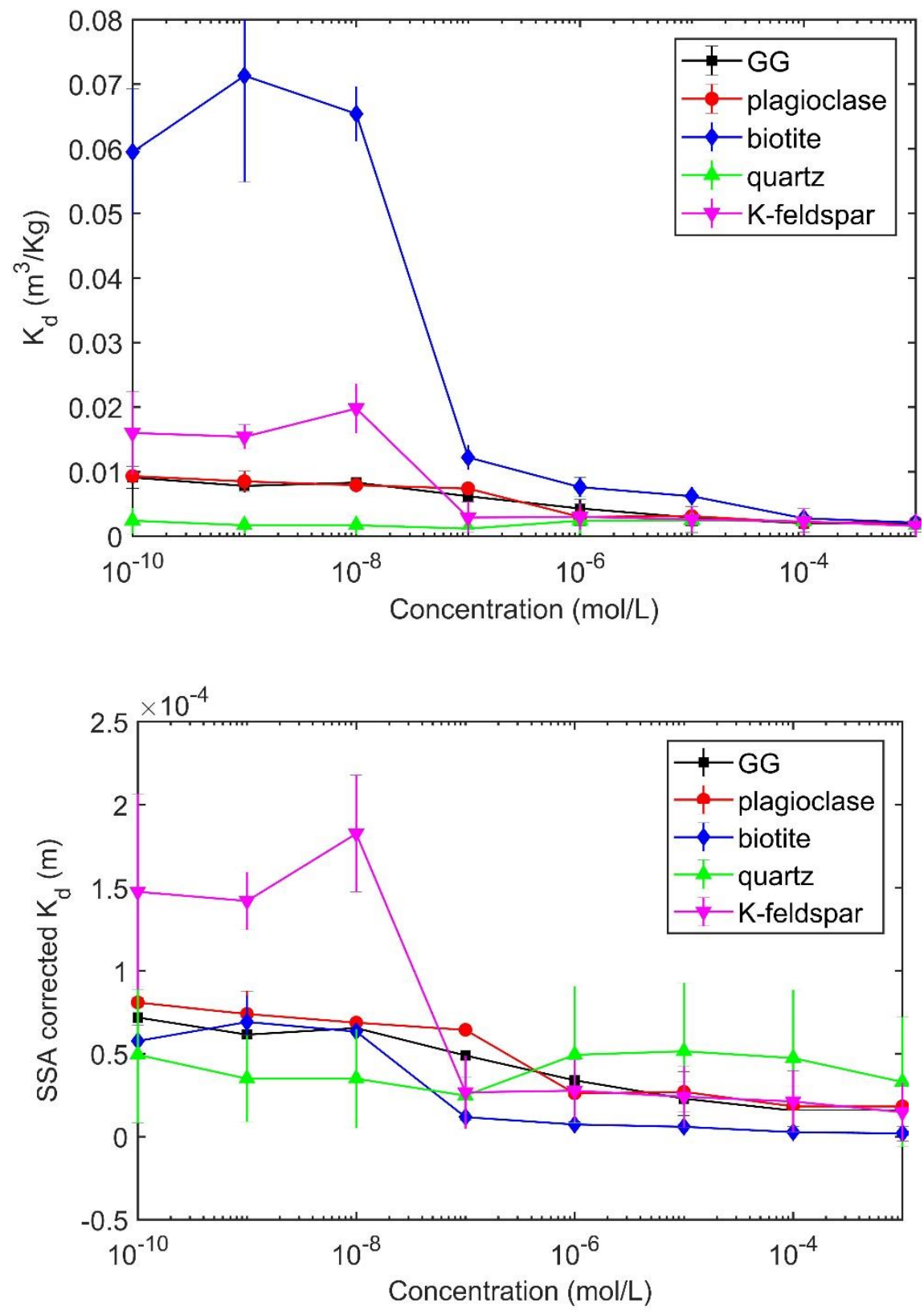
Figure 4. Sorption of Se(IV) on Grimsel granodiorite (GG) and its main minerals ( $\square$,Grimsel granodiorite; $\bullet$, plagioclase; $\bullet$, biotite; $\boldsymbol{\Lambda}$, quartz; $\boldsymbol{\nabla}$, K-feldspar) depending on $\mathrm{Se}(\mathrm{IV})$ concentrations from $10^{-10} \mathrm{M}$ to $10^{-3} \mathrm{M}$ in a background solution of Grimsel groundwater simulant. (a): $\mathrm{K}_{\mathrm{d}}$ values as a function of $\mathrm{Se}(\mathrm{IV})$ concentration; (b): the SSA corrected $\mathrm{K}_{\mathrm{d}}$ values as a function of $\mathrm{Se}(\mathrm{IV})$ concentrations.

Table 7. The results of $\mathrm{K}_{\mathrm{d}}$ values $\left(\mathrm{m}^{3} / \mathrm{Kg}\right)$ of selenium sorption on Grimsel granodiorite and its main minerals analyzed from batch sorption experiments. In the high concentration part $\left(10^{-6} \mathrm{M}\right.$ to $\left.10^{-3} \mathrm{M}\right)$, stable sodium selenite was used as selenium tracer. In the low concentration part $\left(10^{-10} \mathrm{M}\right.$ to $10^{-7} \mathrm{M}$ ), the stable sodium selenium was added to the samples together with a radiotracer of Se-

75.

\begin{tabular}{cccccc}
\hline \multirow{2}{*}{$\begin{array}{c}\text { Concentration } \\
\text { mol/L) }\end{array}$} & \multicolumn{5}{c}{$\mathrm{K}_{\mathrm{d}}\left(\times 10^{-3}\right)\left(\mathrm{m}^{3} / \mathrm{Kg}\right)$} \\
\cline { 2 - 6 } & grimsel & Plagio- & Biotite & Quartz & K-feldspar \\
\hline $1 \times 10^{-10}$ & $9.1 \pm 1.7$ & $9.3 \pm 0.3$ & $59.5 \pm 9.7$ & $2.4 \pm 2.0$ & $16.0 \pm 6.4$ \\
$1 \times 10^{-9}$ & $7.8 \pm 1.0$ & $8.5 \pm 1.6$ & $71.3 \pm 16.4$ & $1.7 \pm 1.3$ & $15.4 \pm 1.9$ \\
$1 \times 10^{-8}$ & $8.3 \pm 0.4$ & $7.9 \pm 0.2$ & $65.4 \pm 4.2$ & $1.7 \pm 1.4$ & $19.8 \pm 3.8$ \\
$1 \times 10^{-7}$ & $6.2 \pm 0.3$ & $7.4 \pm 0.2$ & $12.2 \pm 1.9$ & $1.2 \pm 0.5$ & $2.9 \pm 2.4$ \\
$1 \times 10^{-6}$ & $4.0 \pm 1.3$ & $2.7 \pm 1.3$ & $7.6 \pm 1.5$ & $2.4 \pm 2.0$ & $3.0 \pm 2.0$ \\
$1 \times 10^{-5}$ & $2.6 \pm 1.2$ & $2.8 \pm 1.3$ & $6.2 \pm 1.4$ & $2.5 \pm 2.0$ & $2.6 \pm 2.0$ \\
$1 \times 10^{-4}$ & $1.7 \pm 1.3$ & $1.8 \pm 1.3$ & $2.8 \pm 1.4$ & $2.3 \pm 2.0$ & $2.3 \pm 2.0$ \\
$1 \times 10^{-3}$ & $1.7 \pm 1.3$ & $1.8 \pm 1.3$ & $2.1 \pm 1.4$ & $1.6 \pm 1.9$ & $1.6 \pm 1.9$
\end{tabular}


SSA corrected

$$
\mathrm{K}_{\mathrm{d}}\left(\times 10^{-5} \mathrm{~m}\right)^{*}
$$

$$
6.15 \pm 0.79 \quad 7.39 \pm 1.39 \quad 6.91 \pm 1.59 \quad 3.50 \pm 2.67 \quad 14.2 \pm 1.75
$$

*: The SSA corrected $\mathrm{K}_{\mathrm{d}}$ values were calculated with the $\mathrm{K}_{\mathrm{d}}$ data of $10^{-9} \mathrm{M} \mathrm{Se}(\mathrm{IV})$ concentration and the SSA data in table 3.

$\mathrm{Se}(\mathrm{IV})$ has the second largest $\mathrm{K}_{\mathrm{d}}$ values on $\mathrm{K}$-feldspar in the low concentration area, though the $K_{d}$ values are about 4 times lower than those on biotite (Table 7). The relatively high $K_{d}$ values of Se on K-feldspar than on plagioclase and Grimsel granodiorite, which have similar mineral structures as K-feldspar, might be due to the inhomogeneity of the samples as the K-feldspar was only $90 \%$ pure and some impurities which have high selenium sorption abilities might exist.

The distribution coefficients of Se(IV) on quartz were found to be negligible in the whole concentration areas. This is due to the very small SSA of quartz resulting in the scarce of sorption sites.

The $\mathrm{K}_{\mathrm{d}}$ values of $\mathrm{Se}(\mathrm{IV})$ on Grimsel granodiorite and plagioclase are almost the same through the whole concentration range whereas the one on K-feldspar is about twice as high. If we compare the compositions of Grimsel granodiorite and plagioclase shown in Table 5, one can find the similarities of these two samples. $65 \%$ of Grimsel granodiorite is composed of feldspar group minerals (40\% plagioclase and $25 \% \mathrm{~K}$-feldspar) together with $20 \%$ of quartz, $10 \%$ of biotite and $5 \%$ of chlorite. In the plagioclase mineral sample, $80 \%$ compositions are feldspar group minerals (75\% plagioclase and 5\% K-feldspar) together with $5 \%$ biotite and other minerals like quartz and amphibole in low compositions. The main compositions of these two samples are feldspars (plagioclase and Kfeldspar) while the difference is that Grimsel granodiorite has $20 \%$ of quartz and $5 \%$ of biotite. The quite similar sorption behaviors of Se(IV) on Grimsel granodiorite and plagioclase indicates that the

\begin{tabular}{|c|c|c|c|c|}
\hline Author & Title & File Name & Date & Page \\
\hline Xiaodong Li et al. & $\begin{array}{l}\text { Sorption of Se species on mineral surfaces, Part I: Batch sorption and } \\
\text { multi-site modelling }\end{array}$ & $\begin{array}{l}\text { Xiaodong_et_al__ } \\
\text { manuscript }\end{array}$ & 08.12 .2019 & $26(43)$ \\
\hline
\end{tabular}
influence of $20 \%$ of quartz in Grimsel granodiorite was compensated by the surplus of biotite. This 
also results in the very similar SSA values of them (Table 6). The $\mathrm{K}_{\mathrm{d}}$ values for both Grimsel granodiorite and plagioclase didn't change much in low concentrations range and they varied between $0.0062 \pm 0.0003 \mathrm{~m}^{3} / \mathrm{Kg}$ to $0.0093 \pm 0.0003 \mathrm{~m}^{3} / \mathrm{Kg}$.

There is a linear relation between SSA and the distribution coefficients among all the rock samples, as can be seen in Figure 5. Table 7 also shows the SSA corrected $\mathrm{K}_{d}$ values of Se(IV) on Grimsel granodiorite and its main minerals. It can be noticed that the $\mathrm{K}_{\mathrm{d}}$ values become closer with each other when SSA is taken into consideration (Figure 4, down). Though biotite has the largest sorption capacity compared with the other rock samples, the SSA corrected $\mathrm{K}_{\mathrm{d}}$ values of $\mathrm{Se}(\mathrm{IV})$ on biotite are quite similar with the ones for Grimsel granodiorite and plagioclase. All these three rock samples have the SSA corrected $\mathrm{K}_{\mathrm{d}}$ values around $6-7 \times 10^{-5} \mathrm{~m}$ except $\mathrm{K}$-feldspar. This proves that the high sorption ability of biotite comes mainly from its high SSA which provides more sorption sites for Se on biotite. The SSA corrected $\mathrm{K}_{\mathrm{d}}$ values of Se(IV) on K-feldspar was unexpectedly large, about 2 times higher than those on Grimsel granodiorite, plagioclase and biotite. This might be due to the inhomogeneity of the samples and some impurities contained in the minerals, for example, chlorite which is known to be a highly sorbing mineral of Se(IV) (Söderlund et al., 2016b). However, further studies are ongoing to explain this phenomenon. The sorption ability of quartz is still the smallest even corrected with SSA. The reason of this can be found in the crystalline structure of it. The relative stabilities of primary silicates have an increasing relation with the increasing Si to O ratio which continues through the amphiboles $(0.364)$, the micas $(0.4)$ and to the tectosilicates (0.5) (Essington, 2015). Quartz is one member of the tectosilicate family and it is composed of a three-dimensional network of Si tetrahedron in which each oxygen atom is shared by neighboring tetrahedron. In the structure of quartz, all the tetrahedrons share their four $\mathrm{O}^{2-}$ with the neighboring tetrahedrons. The maximum sharing of oxygen atoms imparts greater structural stability as a result of the high percentage of covalent character in the $\mathrm{Si}-\mathrm{O}$ bond. This means that the

$\begin{array}{lll}\text { Author } & \text { Title } & \text { File Name } \\ \text { Xiaodong Li et al. } & \begin{array}{l}\text { Sorption of Se species on mineral surfaces, Part I: Batch sorption and } \\ \text { multi-site modelling }\end{array} & \begin{array}{l}\text { Xiaodong_et_al__ } \\ \text { manuscript }\end{array}\end{array}$


surface of quartz is quite inactive and not easy to react with other ions, imparting the high stability of quartz.

According to the theory mentioned above, the sorption of Se(IV) ions can be roughly described in the following sequence: tectosilicates < phyllosilicates < inosilicates (Essington, 2015; Söderlund et al., 2015). This sequence can be shown clearly in Figure 5 as the distinctive larger $K_{d}$ value of selenium on biotite than the other four rock samples, because biotite is a member of phyllosilicate while plagioclase, K-feldspar and quartz are the members of tectosilicate. $85 \%$ of Grimsel granodiorite are composed of tectosilicate minerals (40\% plagioclase, 25\% feldspar, 20\% quartz, see Table 5), so Grimsel granodiorite can be roughly grouped to the tectosilicate family when we discuss about the results of this experiment.

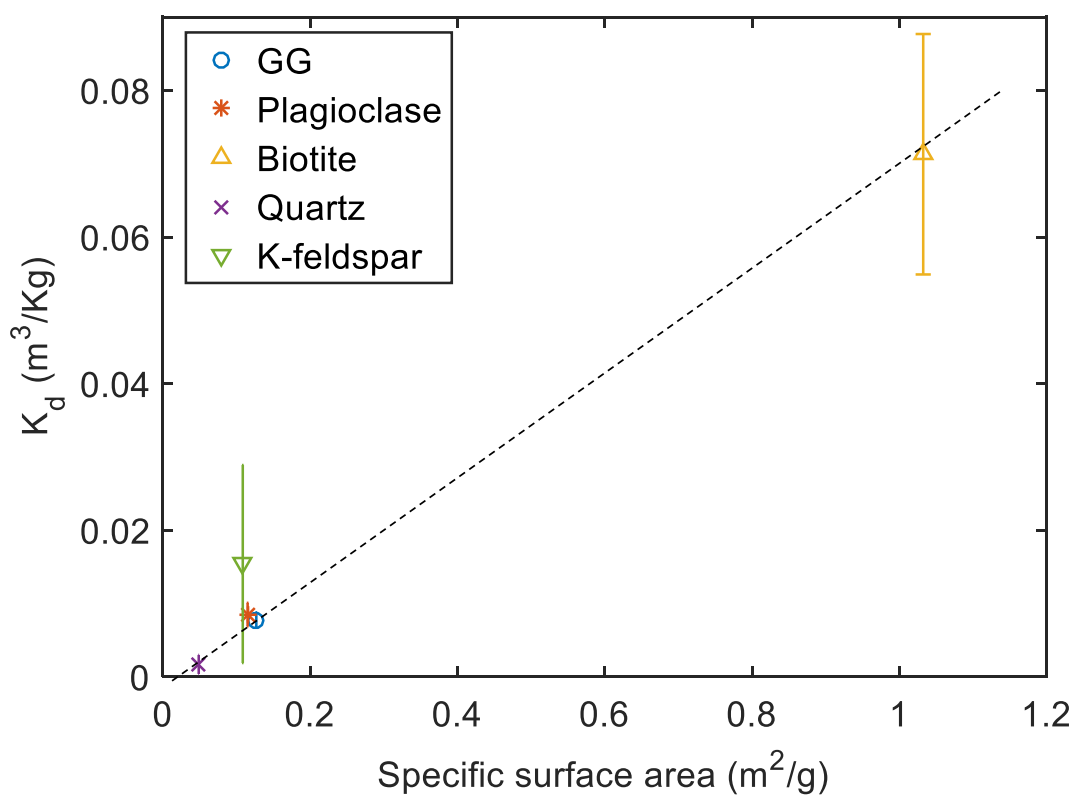

Figure 5. Distribution coefficients of Se(IV) on Grimsel granodiorite and its main minerals as a function of their specific surface area in $10^{-9} \mathrm{M} \mathrm{Se}(\mathrm{IV})$ concentration. 


\subsection{Modelling}

\subsubsection{Sorption modelling with isotherm equations}

The sorption isotherms of Grimsel granodiorite and its main minerals and the fitted line of Grimsel granodiorite and biotite are shown in Figure 6. The linear relation between the amount of sorbed $\mathrm{Se}(\mathrm{IV})$ and the amount of $\mathrm{Se}(\mathrm{IV})$ remaining in the Grimsel groundwater simulant fits to the Freundlich equation (Equation 4). The parameters of the Freundlich equation, $\mathrm{K}_{\mathrm{f}}$ and $\mathrm{n}$ constants were calculated for all the rock and mineral samples and are shown in Table 8 .

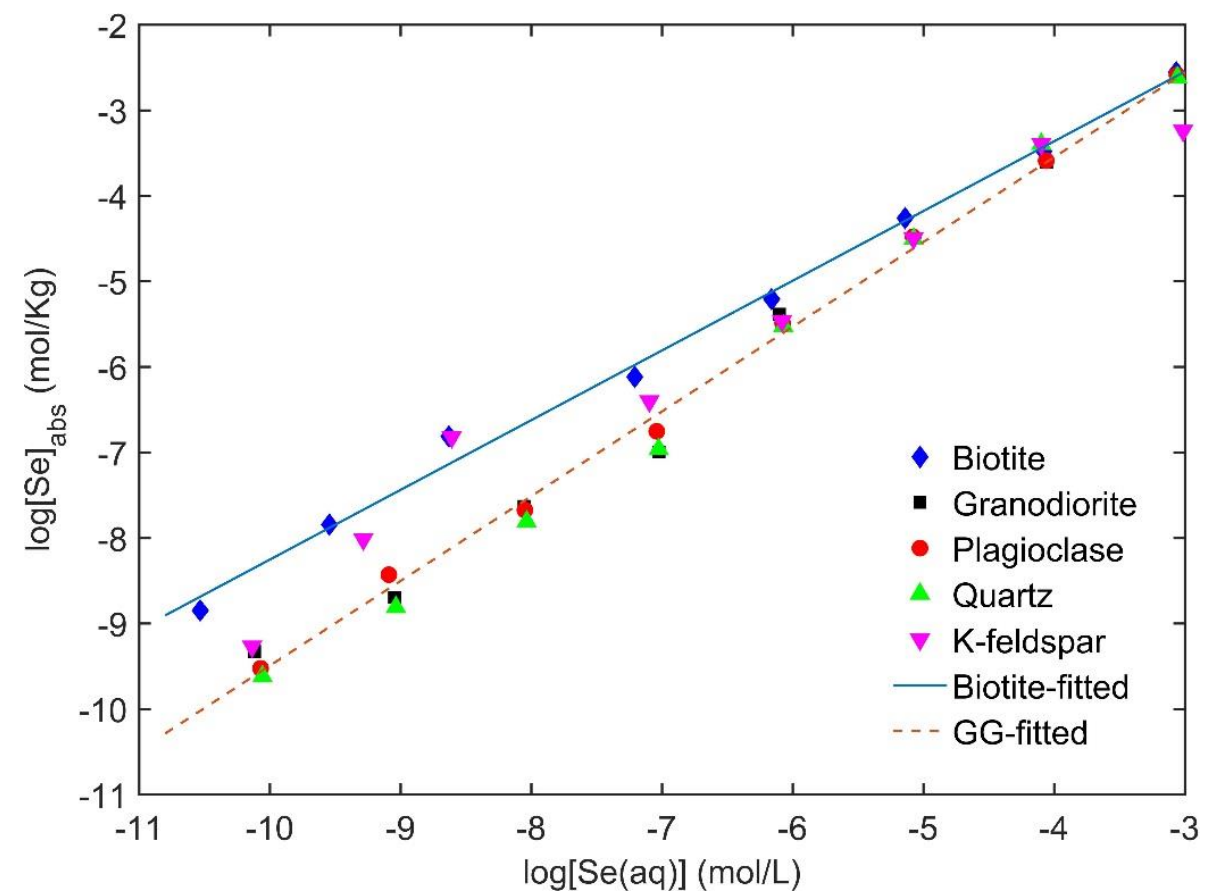

Figure 6. Sorption isotherms for Se(IV) sorption onto Grimsel granodiorite and its main minerals ( $\boldsymbol{\bullet}$,Grimsel granodiorite; $\bullet$, plagioclase; $\bullet$, biotite; $\boldsymbol{\Delta}$, quartz; $\boldsymbol{\nabla}, \mathrm{K}$-feldspar) in Grimsel groundwater simulant. Solid line (-) correspond to the fitted curve of biotite isotherm and dashed line (---) the fitted curve of Grimsel granodiorite.

Author

Xiaodong Li et al.
Title

Sorption of Se species on mineral surfaces, Part I: Batch sorption and multi-site modelling
File Name Date Page

Xiaodong_et_al $\quad 08.12 .2019 \quad 29(43)$ manuscript 
Table 8. The values of $\mathrm{K}_{\mathrm{f}}$ and $\mathrm{n}$ in the Freundlich equation $\Gamma=K_{f} C^{n}$ calculated from the regression analysis of $\log \Gamma-\log C$ sorption isotherm in Figure 6.

\begin{tabular}{|c|c|c|c|c|c|}
\hline Freundlich & Grimsel & Plagioclase & Biotite & Quartz & K-feldspar \\
Para. & granodiorite & & & & \\
\hline $\mathrm{K}_{\mathrm{f}}$ & 2.5858 & 2.8708 & 0.7871 & 5.0968 & 0.4446 \\
\hline $\mathrm{n}$ & 0.9907 & 0.9938 & 0.8150 & 1.046 & 0.8296 \\
\hline
\end{tabular}

Figure 6 shows that at both low concentration area and high concentration area, the sorption of Se(IV) on Grimsel granodiorite and the main minerals can be described by Freundlich equation. For Grimsel granodiorite, plagioclase and quartz, the exponent constants in Freundlich equation are quite near 1 , this means that the amount of Se(IV) sorbed on these rock samples increased linearly with the increase of $\mathrm{Se}(\mathrm{IV})$ concentration in the groundwater simulant across the whole concentration range tested $\left(10^{-3} \mathrm{M}\right.$ to $\left.10^{-10} \mathrm{M}\right)$. For biotite and $\mathrm{K}$-feldspar, the $\mathrm{n}$ values are around 0.82 , signifying that when the concentration of Se(IV) in groundwater simulant increased, the relative adsorption decreased. This kind of sorption type is usually caused by the saturation of adsorption sites available on the surface of rock samples, resulting in the relatively less sorption.

The fitting of Langmuir equation can be checked by fitting experimental data into equation 6 , by plotting the ratio of sorbed $\mathrm{Se}(\mathrm{IV})$ concentrations to its aqueous concentrations as a function of aqueous concentrations. However, the non-linearity of fitting results clearly shows that the sorption of Se(IV) on Grimsel granodiorite and its main minerals cannot be described by using Langmuir equation (an example of Grimsel granodiorite in Figure 7).

Author

Xiaodong Li et al.
Title

Sorption of Se species on mineral surfaces, Part I: Batch sorption and multi-site modelling

$\begin{array}{lll}\text { File Name } & \text { Date } & \text { Page } \\ \begin{array}{l}\text { Xiaodong_et_al_ } \\ \text { manuscript }\end{array} & \text { 08.12.2019 } & 30(43)\end{array}$




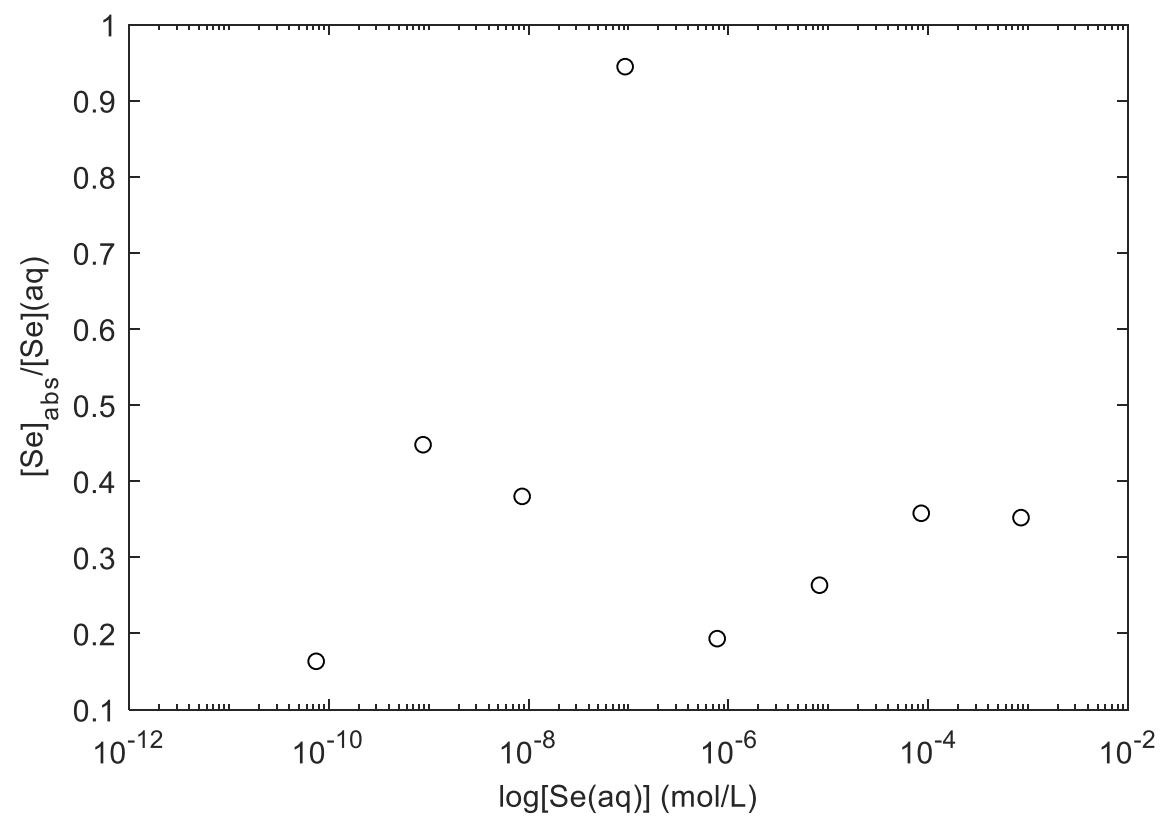

Figure 7. The ratio of Se(IV) sorbed concentration to the aqueous concentration as a function of $\mathrm{Se}(\mathrm{IV})$ aqueous concentration remaining in the Grimsel groundwater simulant after batch sorption experiments of the Grimsel granodiorite.

\subsubsection{Surface complexation modelling of selenite on biotite}

According to Figure 4, the sorption data of Se(IV) on biotite was chosen for surface complexation modelling because the highest sorption ability of biotite gives an obvious description of the different sorption behaviors in high and low concentration areas. In addition, the sorption behaviors on Grimsel granodiorite, plagioclase and quartz are described well with Freundlich equations.

Surface complexation modelling was carried out supposing the surface complexation reactions of the two main selenium species $\left(\mathrm{HSeO}_{3}{ }^{-}\right.$and $\left.\mathrm{SeO}_{3}{ }^{2-}\right)$ at $\mathrm{SOH}$ sites with Grimsel groundwater simulant as background electrolyte (Table 1). The main sorption species $\left(\mathrm{Ca}^{2+}\right.$ and $\left.\mathrm{SO}_{4}{ }^{2-}\right)$ in the water were also considered in the modelling process. The main parameters and surface reactions are listed in Tables 2 to 4. The calculated results of sorption modelling on phlogopite (magnesium end member of biotite) which is $100 \%$ pure according to XRD results are shown in Figure 8.

$\begin{array}{lll}\text { Author } & \text { Title } & \text { File Name } \\ \text { Xiaodong Li et al. } & \begin{array}{l}\text { Sorption of Se species on mineral surfaces, Part I: Batch sorption and } \\ \text { multi-site modelling }\end{array} & \begin{array}{l}\text { Xiaodong_et_al_ } \\ \text { manuscript }\end{array}\end{array}$


The solid line in Figure 8 calculated using three sorption sites model reproduces the experimental sorption isotherm data well. The model predicts that the sorption occures on all sites simultaneously but different sites dominate the Se(IV) sorption in different concentration ranges. The strong sites which have high affinity but low site densities $\left(0.001\right.$ sites $\left./ \mathrm{nm}^{2}\right)$ dominate the $\mathrm{Se}(\mathrm{IV})$ sorption when the concentration of $\mathrm{Se}(\mathrm{IV})$ is lower than $1 \times 10^{-8} \mathrm{M}$. R. Dähn et al. studied the nature of the strong sorption binding sites by using polarized extended X-ray absorption fine structure (P-EXAFS) method (Dähn et al., 2011). The results show that strong sorption happens onto the mineral surface as a mixture of surface complexes bound to the edge sites of the cis-vacant (cv) and trans-vacant (tv) of $\mathrm{Al}$ octahedrons.

As the Se concentration increases the strong sorption sites quickly become saturated due to their low capacity. When the Se(IV) concentrations are higher than $10^{-7} \mathrm{M}$, the contribution of weak sorption sites which have much higher site density (4.6 sites $/ \mathrm{nm}^{2}$ altogether) starts to become important. The nature of the weak sites was modelled by using quantum mechanics CASTEP code implemented into Materials Studio software. The modelling is based on solving the total electronic energy and overall electronic density distribution in order to define the energetically stable structures. The more detailed description of the modelling process could be found in the second part of this work (Puhakka et al., 2018). The modelling results show that two kinds of weak sorption sites exist on the surface of phlogopite with different sorption site densities (Figure 9). The first type of weak site exists on the biotite (001) surface with the site density of 3.2 sites/nm². The sorption reactions on this kind of site are based on ionic forces and Se species are mainly sorbed through cation exchange reactions. The second type of weak site exists on the biotite (110) edge surfaces with the site density of 1.4 sites $/ \mathrm{nm}^{2}$. Se species are sorbed on this kind of site through hydrogen bonding between the Se species and the mineral surfaces.

Author Xiaodong Li et al.
Title

Sorption of Se species on mineral surfaces, Part I: Batch sorption and multi-site modelling

$\begin{array}{lll}\text { File Name } & \text { Date } & \text { Page } \\ \begin{array}{l}\text { Xiaodong_et_al__ } \\ \text { manuscript }\end{array} & \text { 88.12.2019 } & 32(43)\end{array}$


The saturation point of strong sorption sites happens when Se(IV) in the solution was around $10^{-8}$ $\mathrm{M}$ and the amount of $\mathrm{Se}(\mathrm{IV})$ sorbed was $1.5 \times 10^{-7} \mathrm{~mol} / \mathrm{Kg}$ dry biotite. At this point, the sorption of Se(IV) was sensitive to both strong and weak sorption sites. The effect of strong and weak sorption sites can be seen from Figure 10. In both high and low concentration ranges, the sorption of Se(IV) increased linearly with the increase of Se(IV) while there is a clear change of sorption sites when the selenium concentration was about $10^{-8} \mathrm{M}$ in aqueous solution, indicating the changing of site types and sorption mechanisms.

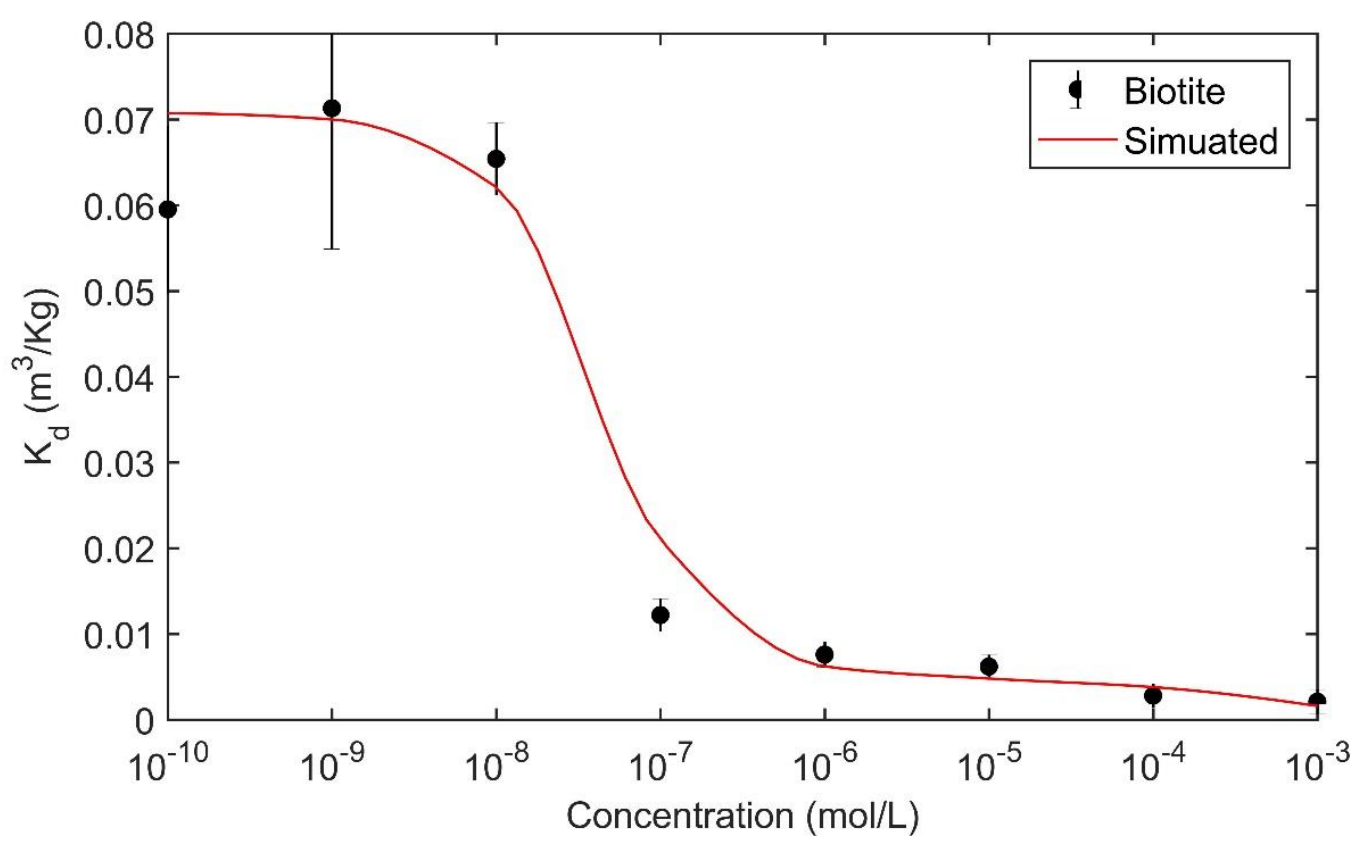

Figure 8. Experimental data of Se(IV) sorption on biotite in Grimsel groundwater simulant as a function of Se concentration $\left(10^{-10} \mathrm{M}-10^{-3} \mathrm{M}\right.$ and the continuous line is the simulated data with surface complexation model. The parameters are given in Table 2 to 4 .

Author

Xiaodong Li et al.
Title

Sorption of Se species on mineral surfaces, Part I: Batch sorption and multi-site modelling
File Name Date Page

Xiaodong_et_al_ $08.12 .2019 \quad 33(43)$ manuscript 

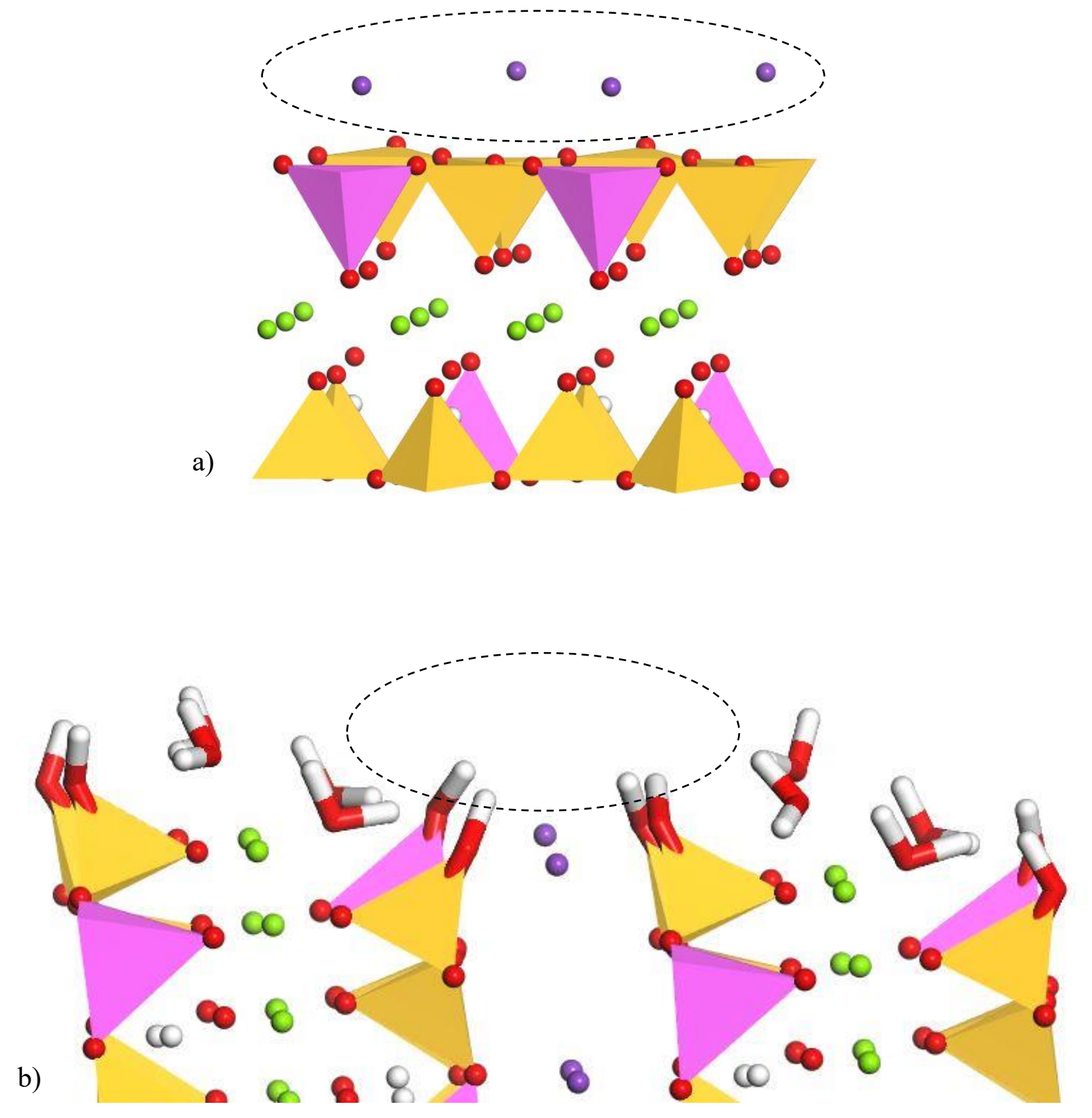

Figure 9. Weak sorption sites of phlogopite marked with the dashed line: a) the (001) basal surface and $b)$ the (110) edge surface.

Author

Xiaodong Li et al.
File Name

Date

Page

Xiaodong_et_al_ 08.12.2019 manuscript 


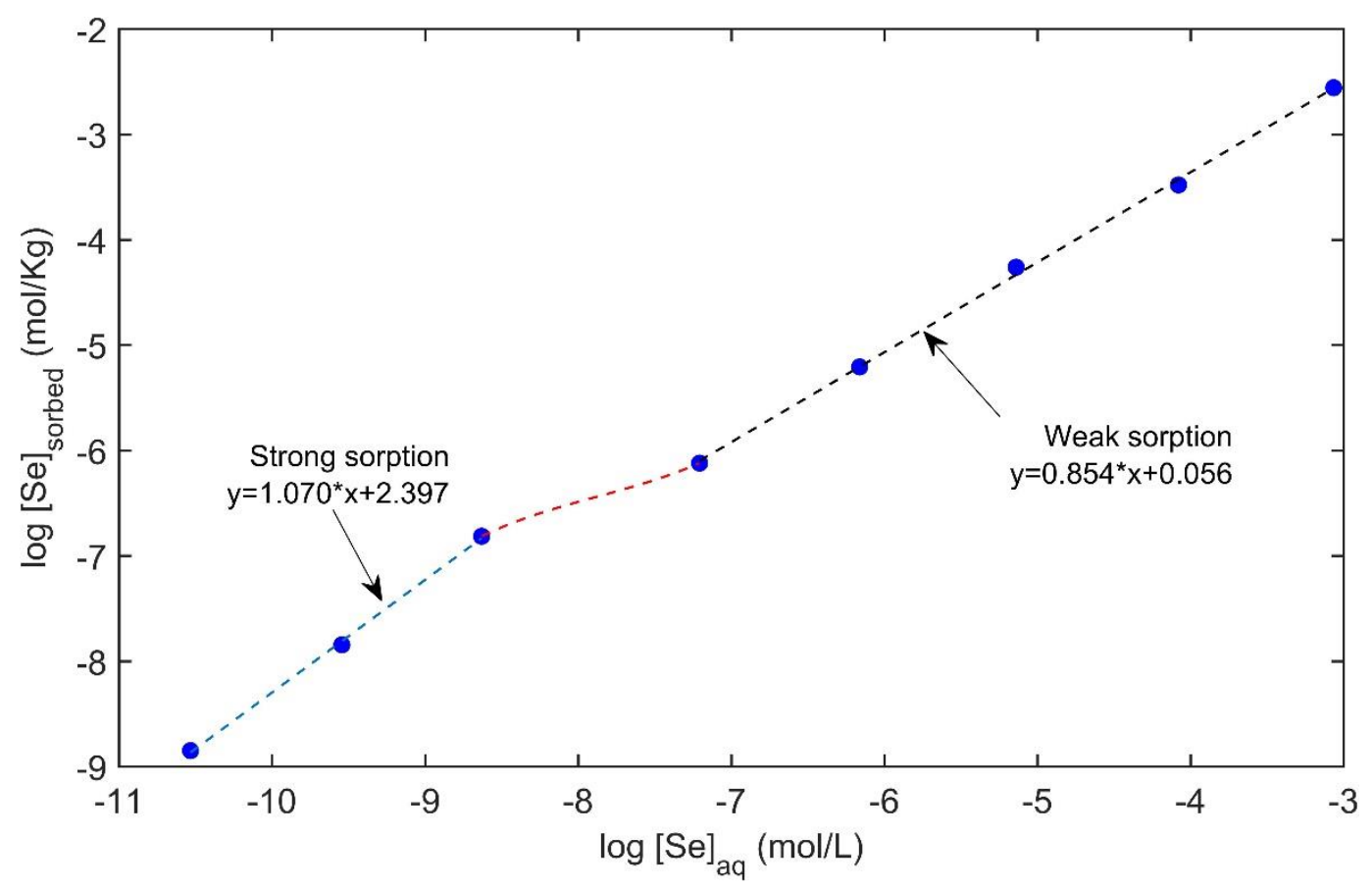

Figure 10. Effect of strong and weak sorption sites in low and high concentration range.

\section{Conclusions}

$\mathrm{Se}(\mathrm{IV})$ sorption was investigated on Grimsel granodiorite and the main minerals in Grimsel groundwater simulant. The results suggest that selenium is poorly sorbed in both $\mathrm{HSeO}_{3}{ }^{-}$and $\mathrm{SeO}_{3}{ }^{2-}$ forms under atmospheric conditions when selenium remains in +IV oxidation state. The $\mathrm{K}_{\mathrm{d}}$ values of selenite on Grimsel granodiorite and the main minerals increased with decreasing Se(IV) concentrations. Selenite has the largest $\mathrm{K}_{d}$ values on biotite in the low concentration range $\left(<10^{-7} \mathrm{M}\right)$, stabilizing between $0.0595 \pm 0.0097 \mathrm{~m}^{3} / \mathrm{Kg}$ and $0.0713 \pm 0.0164 \mathrm{~m}^{3} / \mathrm{Kg}$. The $\mathrm{K}_{\mathrm{d}}$ value of selenite on $\mathrm{K}$ feldspar was the second largest, $0.0154 \pm 0.0019 \mathrm{~m}^{3} / \mathrm{Kg}$ in $10^{-9} \mathrm{M}$, while the sorption on quartz could be negligible in the whole concentration area. The sorption behavior of Se(IV) on Grimsel grano-

Author

Xiaodong Li et al.
Title

Sorption of Se species on mineral surfaces, Part I: Batch sorption and multi-site modelling
File Name Date Page

Xiaodong_et_al_ $\quad 08.12 .2019 \quad 35(43)$ manuscript 
diorite followed the same trend as on plagioclase, which is the most abundant mineral of it. The distribution coefficient of Se (IV) on Grimsel granodiorite and plagioclase were $0.0078 \pm 0.0010 \mathrm{~m}^{3} / \mathrm{Kg}$ and $0.0085 \pm 0.0016 \mathrm{~m}^{3} / \mathrm{Kg}$ respectively when $\mathrm{Se}(\mathrm{IV})$ concentration was $10^{-9} \mathrm{M}$.

SSA was found to play an important role when comparing the sorption behaviors of selenite on Grimsel granodiorite rock and the main minerals. There is a linear relation between SSA and $\mathrm{K}_{\mathrm{d}}$ values among all the rock samples. When the $\mathrm{K}_{\mathrm{d}}$ values were corrected by SSA, the sorption behavior of biotite was almost the same as that of Grimsel granodiorite and plagioclase. The negligible CEC value of quartz and $\mathrm{K}_{\mathrm{d}}$ values of selenite on it were interpreted as a result of maximum sharing of oxygen atoms and the resulting high percentage of covalent character in the $\mathrm{Si}-\mathrm{O}$ bond.

The sorption isotherms of selenite on Grimsel granodiorite, plagioclase and quartz were described well by Freundlich equation. A multiple site surface complexation model was made with PHREEQC for Se(IV) sorption on biotite and it fits quite well with the experimental data. The model predicts that at least three kinds of sorption sites exist on the surface of biotite. The site densities of two kinds of weak sorption sites were calculated by using molecular modelling and the site density of strong sorption sites were fitted from the surface complexation model. The modelling results show that the amount of weak sorption sites are three magnitudes higher than the amount of strong sorption sites. The sorption behavior of $\mathrm{Se}(\mathrm{IV})$ on biotite was determined by the strong sorption sites when Se(IV) concentration was $\leq 10^{-8} \mathrm{M}$ in the solution while the contribution of weak sorption sites starts to become important in the concentration range $>10^{-7} \mathrm{M}$.

However, the physical properties of the strong and weak sorption sites remain unclear. In the second part of this work, DFT modelling was used to interpret the properties of the weak sorption sites, which gives us a deeper understanding of the sorption mechanism of $\mathrm{Se}(\mathrm{IV})$ on biotite.

$\begin{array}{lll}\text { Author } & \text { Title } & \text { File Name } \\ \text { Xiaodong Li et al. } & \begin{array}{l}\text { Sorption of Se species on mineral surfaces, Part I: Batch sorption and } \\ \text { multi-site modelling }\end{array} & \begin{array}{l}\text { Xiaodong_et_al__ } \\ \text { manuscript }\end{array}\end{array}$




\section{References}

Selenium in drinking water-Background document for development of WHO, World Health Organization 2011.

Altmann, S., 2008. Geochemical research: a key building block for nuclear waste disposal safety cases. Journal of contaminant hydrology 102, 174-179.

ANDRA, 2009. ThermoChimie Version 7b dataset.

Atwood, D.A., 2010. Radionuclides in the Environment, WILEY.

Boult, K.A., Cowper, M.M., Heath, T.G., Sato, H., Shibutani, T., Yui, M., 1998. Towards an understanding of the sorption of U(VI) and Se(IV) on sodium bentonite. Journal of contaminant hydrology $35,141-150$.

Bradbury, M.H., Baeyens, B., 1995. A Quantitative Mechanistic Description of Ni, Zn and Ca Sorption on Na-Montmorillonite Part III: Modelling, TECHNICAL REPORT NTB 95-06, Nagra, Wettingen, Switzerland.

Chakraborty, S., Wolthers, M., Chatterjee, D., Charlet, L., 2007. Adsorption of arsenite and arsenate onto muscovite and biotite mica. J Colloid Interface Sci 309, 392-401.

Ciesielski, H., Sterckeman, T., Santerne, M., Willery, J., 1997. A comparison between three methods for the determination of cation exchange capacity and exchangeable cations in soils. Agronomie, EDP Sciences 17, 9-16.

Dähn, R., Baeyens, B., Bradbury, M.H., 2011. Investigation of the different binding edge sites for $\mathrm{Zn}$ on montmorillonite using P-EXAFS - The strong/weak site concept in the 2SPNE SC/CE sorption model. Geochimica et Cosmochimica Acta 75, 5154-5168.

$\begin{array}{lll}\text { Author } & \text { Title } & \text { File Name } \\ \text { Xiaodong Li et al. } & \begin{array}{l}\text { Sorption of Se species on mineral surfaces, Part I: Batch sorption and } \\ \text { multi-site modelling }\end{array} & \begin{array}{l}\text { Xiaodong_et_al__ } \\ \text { manuscript }\end{array}\end{array}$


De Cannière, P., Maes, A., Williams, S., Bruggeman, C., Beauwens, T., Maes, N., Cowper, M., 2010. Behaviour of Selenium in Boom Clay, SCK•CEN ref: CO 90011467.011467

Duc, M., Lefevre, G., Fedoroff, M., Jeanjean, J., Rouchaud, J.C., Monteil-Rivera, F., Dumonceau, J., Milonjic, S., 2003. Sorption of selenium anionic species on apatites and iron oxides from aqueous solutions. Journal of Environmental Radioactivity 70, 61-72.

Eikenberg, J., Hoehn, E., Fierz, T., U.Frick, 1994. Grimsel Test Site: Preparation and performance of migration experiments with radioisotoQS of sodium, strontium and iodine.

Ervanne, H., Hakanen, M., Lehto, J., 2016. Selenium sorption on clays in synthetic groundwaters representing crystalline bedrock conditions. Journal of Radioanalytical and Nuclear Chemistry 307, 1365-1373.

Ervanne, H., Puukko, E., Hakanen, M., 2013. Modeling of Sorption of Eu, Mo, Nb, Ni, Pa, Se, Sn, Th and U on Kaolinite and Illite in Olkiluoto Groundwater Simulants, Laboratory of Radiochemitry, Department of Chemistry, University of Helsinki.

Essington, M.E., 2015. Soil and Water Chemistry: An Integrative Approach. CRC Press.

Ewing, R.C., 2015. Long-term storage of spent nuclear fuel. Nature Materials 14, 252-257.

Freundlich, H., Kapillarchemie, eine Darstellung der Chemie, 1909. Kolloide und verwandter Gebiete.

Grambow, B., 2008. Mobile fission and activation products in nuclear waste disposal. Journal of contaminant hydrology 102, 180-186.

Grisak, G.E., Pickens, J.F., 1980. Solute transport through fractured media: 1. The effect of matrix diffusion. Water Resources Research 16, 719-730.

Author

Xiaodong Li et al.
Title

Sorption of Se species on mineral surfaces, Part I: Batch sorption and multi-site modelling
File Name Date Page

Xiaodong_et_al_ $\quad 08.12 .2019 \quad 38(43)$ manuscript 
Hoehn, E., Eikenberg, J., Fierz, T., Drost, W., Reichlmayr, E., 1998. The Grimsel Migration Experiment: field injection-withdrawal experiments in fractured rock with sorbing tracers. Journal of contaminant hydrology 34, 85-106.

Iida, Y., Yamaguchi, T., Tanaka, T., 2013. Sorption behavior of hydroselenide (HSe-) onto ironcontaining minerals. Journal of Nuclear Science and Technology 51, 305-322.

Ikonen, J., Sardini, P., Jokelainen, L., Siitari-Kauppi, M., Martin, A., Eickenberg, J., 2016a. The tritiated water and iodine migration in situ in Grimsel granodiorite. Part I: determination of the diffusion pro-files. J. Radioanal. Nucl. Chem 310, 1041-1048.

Ikonen, J., Voutilainen, M., Soderlund, M., Jokelainen, L., Siitari-Kauppi, M., Martin, A., $2016 b$. Sorption and diffusion of selenium oxyanions in granitic rock. Journal of contaminant hydrology 192, 203-211.

Jokelainen, L., Meski, T., Lindberg, A., Soler, J.M., Siitari-Kauppi, M., Martin, A., Eikenberg, J., 2013. The determination of $134 \mathrm{Cs}$ and $22 \mathrm{Na}$ diffusion profiles in granodiorite using gamma spectroscopy. Journal of Radioanalytical and Nuclear Chemistry 295, 2153-2161.

Kelokaski, M., Siitari-Kauppi, M., Sardini, P., Möri, A., Hellmuth, K.H., 2006. Characterisation of pore space geometry by 14C-PMMA impregnation—development work for in situ studies. Journal of Geochemical Exploration 90, 45-52.

Kyllönen, J., Hakanen, M., Lindberg, A., Harjula, R., Vehkamäki, M., Lehto, J., 2014. Modeling of cesium sorption on biotite using cation exchange selectivity coefficients. Radiochimica Acta 102, 919-929.

Author

Xiaodong Li et al.
Title

Sorption of Se species on mineral surfaces, Part I: Batch sorption and multi-site modelling
File Name Date Page

Xiaodong_et_al_ $08.12 .201939(43)$ 
Lahdenperä, A.-M., 2009. Summary of the Overburden Studies of the Soil Pits OL-KK14, OL-

KK15, OL-KK16, OL-KK17, OL-KK18 and OL-KK19 at Olkiluoto, Eurajoki in 2008, Working Report 2009-109, Pöyry Environment Oy.

Langmuir, I., 1918. The Adsorption of Gases on Plane Surface of Glass, Mica and Platinum. The Research Laboratory of The General Electric Company 40, 1361-1402.

Lehto, J., Hou, X., 2011a. Chemistry and Analysis of Radionuclides Laboratory Techiques and Methodology. WILEY-VCH.

Lehto, J., Hou, X., 2011b. Chemistry and Analysis of Radionuclides Laboratory Techniques and Methodology, WILTY-VCH.

Lehto, J., Hou, X., 2011c. Chemistry and Analysis of Radionuclides: Laboratory Techniques and Methodology. Wiley-VCH.

Linberg, P., 1968. Selenium determination in plant and animal material, and in water: A methodological study. Skandinavisk bladforlag.

Mäder, U.K., Fierz, T., Frieg, B., Eikenberg, J., Rüthi, M., Albinsson, Y., Möri, A., Ekberg, S., Stille, P., 2006. Interaction of hyperalkaline fluid with fractured rock: Field and laboratory experiments of the HPF project (Grimsel Test Site, Switzerland). Journal of Geochemical Exploration 90, 68-94.

Missana, T., Alonso, U., Garcia-Gutierrez, M., 2009. Experimental study and modelling of selenite sorption onto illite and smectite clays. J Colloid Interface Sci 334, 132-138.

Muuri, E., 2015. The sorption and diffusion of Ba_133 in granitic rocks, Department of Chemistry. University of Helsinki, p. 76.

Author

Xiaodong Li et al.
Title

Sorption of Se species on mineral surfaces, Part I: Batch sorption and multi-site modelling
File Name Date Page

Xiaodong_et_al_ $08.12 .2019 \quad 40(43)$ 
Muuri, E., Ikonen, J., Matara-aho, M., Lindberg, A., Holgersson, S., Voutilainen, M., Siitari-

Kauppi, M., Martin, A., 2016. Behavior of Cs in Grimsel granodiorite: sorption on main minerals and crushed rock. Radiochimica Acta 104, 575-582.

Muuri, E., Siitari-Kauppi, M., Matara-aho, M., Ikonen, J., Lindberg, A., Qian, L., Koskinen, L., 2017. Cesium sorption and diffusion on crystalline rock: Olkiluoto case study. Journal of Radioanalytical and Nuclear Chemistry 311, 439-446.

National Institute of Advanced Industrial Science and Technology, Research Center for Deep Geological Environments, Natoto TANENO, 2005. Atlas of Eh-pH diagrams.

Neretnieks, I., 1980. Diffusion in the rock matrix: An important factor in radionuclide retardation? Journal of Geophysical Research: Solid Earth 85, 4379-4397.

Posiva Oy, 2012. Safety Case for the Disposal of Spent Nuclear Fuel at Olkiluoto- Features, Events and Processes 2012, POSIVA 2012-07.

Poteri, A., Nordman, H., Pulkkanen, V.-M., Smith, P., 2014. Radionuclide Transport in the Repository Near-Field and Far-Field, POSIVA 2014-02.

Puhakka, E., Li, X., Ikonen, J., Siitari-Kauppi, M., 2018. Sorption of selenium species onto mineral surfaces, part II: DFT study. Applied geochemistry (Submitted).

Scott, R.C., Voegeli, P.T., 1961. Radiochemical analyses of ground and surface water in Colorado. Colorado Water Conservation Board.

Séby, F., Potin-Gautier, M., Giffaut, E., Donard, O.F.X., 1998. Assessing the speciation and the biogeochemical processes affecting the mobility of selenium from a geological repository of radioactive wastesto the biosphere. Analusis 26, 193-198.

Author

Xiaodong Li et al.
Title

Sorption of Se species on mineral surfaces, Part I: Batch sorption and multi-site modelling
File Name Date Page

Xiaodong_et_al_ $08.12 .2019 \quad 41(43)$ 
Smith, M.I., Westfall, B.B., 1937. Further Field Studies on the Selenium Problem in Relation to Public Health Public Health Reports 52, 1375-1384.

Söderlund, M., Hakanen, M., Lehto, J., 2015. Sorption of niobium on boreal forest soil. Radiochimica Acta 103, 859-869.

Söderlund, M., Hakanen, M., Lehto, J., 2016a. Sorption of cesium on boreal forest soil I: the effect of grain size, organic matter and mineralogy. Journal of Radioanalytical and Nuclear Chemistry 309, 637-645.

Söderlund, M., Virkanen, J., Holgersson, S., Lehto, J., 2016b. Sorption and speciation of selenium in boreal forest soil. J Environ Radioact 164, 220-231.

Söderlund, M.J., 2016. SORPTION AND SPECIATION OF RADIONUCLIDES IN BOREAL FOREST SOIL, Department of Chemistry. University of Helsinki, Helsinki.

Soler, J.M., Landa, J., Havlova, V., Tachi, Y., Ebina, T., Sardini, P., Siitari-Kauppi, M., Eikenberg, J., Martin, A.J., 2015. Comparative modeling of an in situ diffusion experiment in granite at the Grimsel Test Site. Journal of contaminant hydrology 179, 89-101.

Svensk Kärnbränslehantering AB, 2013. Äspö Hard Rock Laboratory Annual report 2012, Technical Report: TR-13-10.

Tsai, S.C., Wang, T.H., Li, M.H., Wei, Y.Y., Teng, S.P., 2009. Cesium adsorption and distribution onto crushed granite under different physicochemical conditions. J Hazard Mater 161, 854-861.

Vilks, P., Cramer, J.J., Jensen, M., Miller, N.H., Miller, H.G., Stanchell, F.W., 2003. In situ diffusion experiment in granite: Phase I. Journal of contaminant hydrology 61, 191-202.

Author

Xiaodong Li et al.
Title

Sorption of Se species on mineral surfaces, Part I: Batch sorption and multi-site modelling
File Name Date Page

Xiaodong_et_al_ $08.12 .2019 \quad 42(43)$ 
Vilks, P., Degueldre, C., 1991. Sorption behaviour of 85Sr, 131Iand 137Cs on colloids and suspended particles from the Grimsel Test Site, Switzerland. Applied Geochemistry 6, 553-563.

Widestrand, H., Byegård, J., Cvetkovic, V., Tullborg, E.L., Winberg, A., Andersson, P., SiitariKauppi, M., 2007. Sorbing tracer experiments in a crystalline rock fracture at Äspö (Sweden): 1. Experimental setup and microscale characterization of retention properties. Water Resources Research 43. W10413.

Widestrand, H., Byegård, J., Kersti Nilsson, Höglund, S., Gustafsson, E., 2010. Long Term Sorption Diffusion Experiment (LTDE-SD) Performance of main in situ experiment and results from water phase measurements, SKB R-10-67.

World Health Organization, 2011. Selenium in Drinking water--Background document for development of WHO Guidelines for Drinking-water Quality. 